\title{
ZUSGS
}

Jins

Prepared in cooperation with the Bureau of Reclamation, Washington State Department of Ecology, and the Yakama Nation

\section{Hydrogeologic Framework of Sedimentary Deposits in Six Structural Basins, Yakima River Basin, Washington}

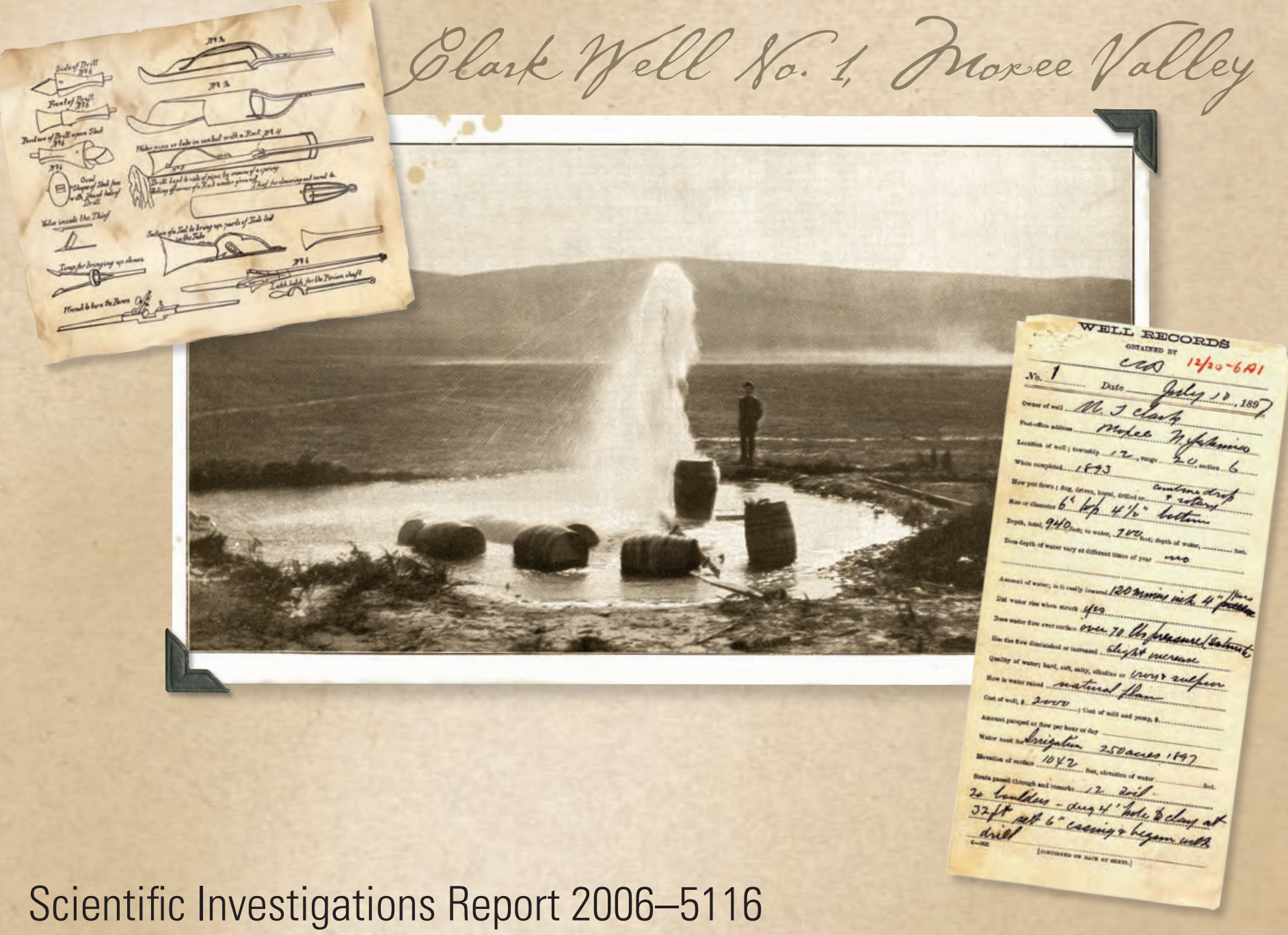

U.S. Department of the Interior U.S. Geological Survey 
Cover: Photograph of Clark Well No. 1, located on the north side of the Moxee Valley in North Yakima, Washington. The well is located in township 12 north, range 20 east, section 6 . The well was drilled to a depth of 940 feet into an artesian zone of the Ellensburg Formation, and completed in 1897 at a cost of $\$ 2,000$. The original flow from the well was estimated at about 600 gallons per minute, and was used to irrigate 250 acres in 1900 and supplied water to 8 small ranches with an additional 47 acres of irrigation. (Photograph was taken by E.E. James in 1897, and was printed in 1901 in the U.S. Geological Survey Water-Supply and Irrigation Paper 55.) 


\section{Hydrogeologic Framework of Sedimentary Deposits in Six Structural Basins, Yakima River Basin, Washington}

By M.A. Jones, J.J. Vaccaro, and A.M. Watkins

Prepared in cooperation with the

Bureau of Reclamation,

Washington State Department of Ecology, and the

Yakama Nation

Scientific Investigations Report 2006-5116 


\section{U.S. Department of the Interior \\ Dirk A. Kempthorne, Secretary \\ U.S. Geological Survey \\ P. Patrick Leahy, Acting Director}

U.S. Geological Survey, Reston, Virginia: 2006

For sale by U.S. Geological Survey, Information Services
Box 25286, Denver Federal Center
Denver, CO 80225
For more information about the USGS and its products:
Telephone: 1-888-ASK-USGS
World Wide Web: http://www.usgs.gov/

Any use of trade, product, or firm names in this publication is for descriptive purposes only and does not imply endorsement by the U.S. Government.

Although this report is in the public domain, permission must be secured from the individual copyright owners to reproduce any copyrighted materials contained within this report.

Suggested citation:

Jones, M.A., Vaccaro, J.J., and Watkins, A.M., 2006, Hydrogeologic framework of sedimentary deposits in six structural basins, Yakima River Basin, Washington: U.S. Geological Survey Scientific Investigations Report 2006-5116, $24 \mathrm{p}$. 


\section{Contents}

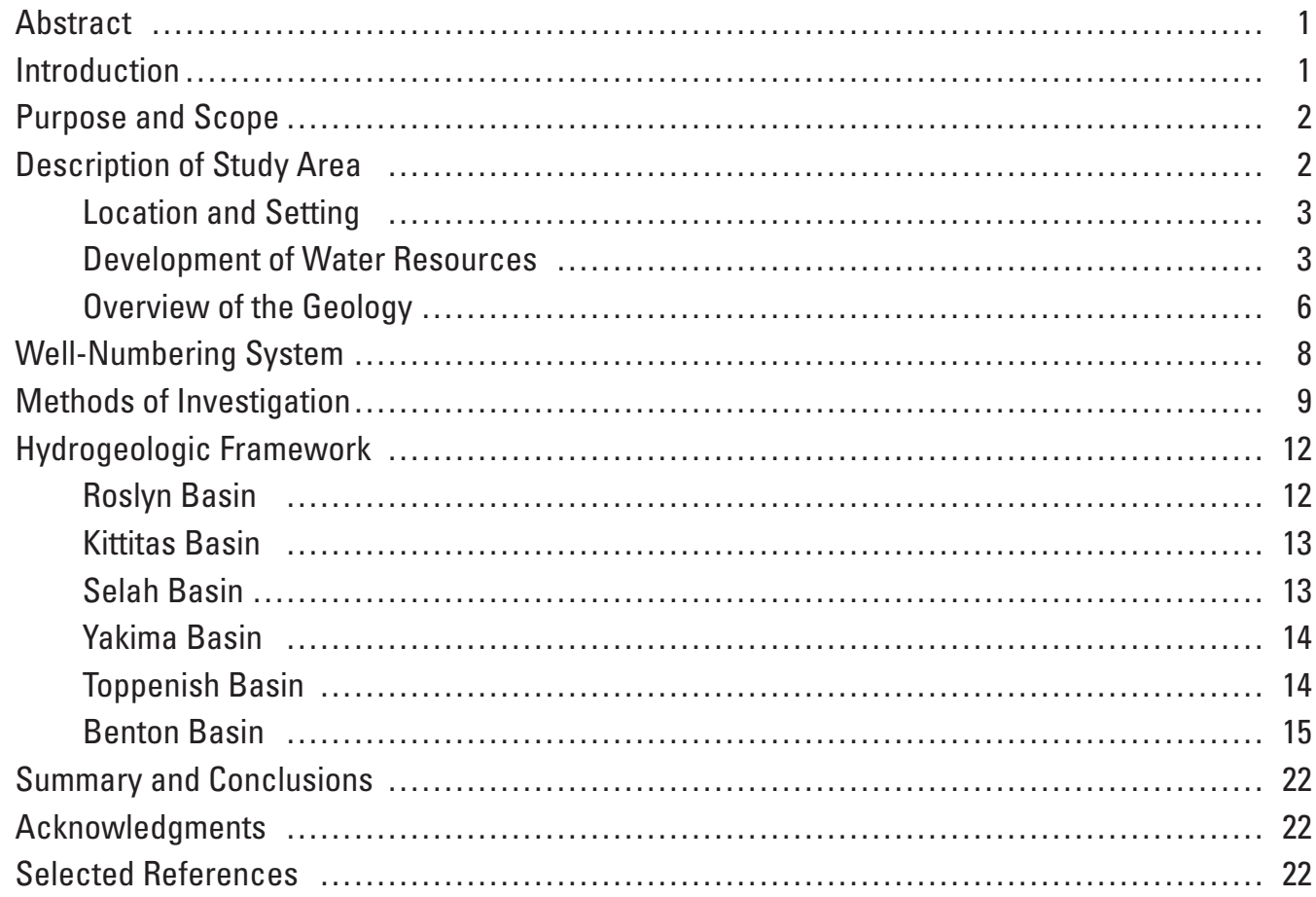

\section{Plates}

Plate 1. Maps and hydrogeologic sections showing surficial geology, extent and thickness of basin-fill deposits, hydrogeologic units, and locations of selected wells in the Roslyn Basin, Yakima River Basin, Washington.

Plate 2. Maps and hydrogeologic sections showing surficial geology, extent and thickness of basin-fill deposits, hydrogeologic units, and locations of selected wells in the Kittitas Basin, Yakima River Basin, Washington.

Plate 3. Maps and hydrogeologic sections showing surficial geology, extent and thickness of basin-fill deposits, hydrogeologic units, and locations of selected wells in the Selah Basin, Yakima River Basin, Washington.

Plate 4. Maps and hydrogeologic sections showing surficial geology, extent and thickness of basin-fill deposits, hydrogeologic units, and locations of selected wells in the Yakima Basin, Yakima River Basin, Washington.

Plate 5. Maps and hydrogeologic sections showing surficial geology, extent and thickness of basin-fill deposits, hydrogeologic units, and locations of selected wells in the Toppenish Basin, Yakima River Basin, Washington.

Plate 6. Maps and hydrogeologic sections showing surficial geology (sheet 1), extent and thickness of basin-fill deposits, hydrogeologic units, and locations of selected wells (sheet 2) in the Benton Basin, Yakima River Basin, Washington. 


\section{Figures}

Figure 1. Map showing the Yakima River Basin, Washington $\ldots \ldots \ldots \ldots \ldots \ldots \ldots \ldots \ldots \ldots \ldots \ldots \ldots \ldots \ldots \ldots \ldots \ldots$

Figure 2. Map showing land use and land cover, Yakima River Basin, Washington, $1999 \quad \ldots \quad 4$

Figure 3. Schematic diagram showing selected tributaries, diversion canals, return flows, and streamflow-gaging stations, Yakima River Basin, Washington $\ldots \ldots \ldots \quad 5$

Figure 4. Map showing simplified surficial geology, Yakima River Basin, Washington $\ldots \ldots .7$

Figure 5. Diagram showing well-numbering systems used in the State of Washington ..... 8

Figure 6. Map showing location of six sedimentary basins, Yakima River Basin, Washington

Figure 7. Map showing structure delineating six sedimentary basins, Yakima River Basin, Washington

Figure 8. Maps showing thickness of subunits 1-6 in northeastern Benton Basin, Yakima River Basin, Washington

\section{Conversion Factors, Datums, and Abbreviations}

Inch/Pound to SI

\begin{tabular}{lcl}
\hline Multiply & By & To obtain length \\
\hline acre & 4,047 & square meter \\
acre-foot (acre-ft) & 1,233 & cubic meter \\
acre-foot (acre-ft) & 0.001233 & cubic hectometer \\
acre-foot per year (acre-ft/yr) & 1,233 & cubic meter per year \\
cubic foot ( $\mathrm{ft}^{3}$ ) & 0.02832 & cubic meter \\
cubic foot per second (ft $\left.{ }^{3} / \mathrm{s}\right)$ & 0.02832 & cubic meter per second \\
foot (ft) & 0.3048 & meter \\
gallon (gal) & 3.785 & liter \\
gallon (gal) & 0.003785 & cubic meter \\
gallon (gal) & 3.785 & cubic decimeter \\
gallon per minute (gal/min) & 0.06309 & liter per second \\
gallon per day (gal/d) & 0.003785 & cubic meter per day \\
inch (in.) & 2.54 & centimeter \\
inch (in.) & 25.4 & millimeter \\
mile (mi) & 1.609 & kilometer \\
million gallons (Mgal) & 3,785 & cubic meter \\
million gallons per day (Mgal/d) & 0.04381 & cubic meter per second \\
section (640 acres or 1 square mile) & 259.0 & square hectometer \\
square foot (ft ${ }^{2}$ ) & 0.09290 & square meter \\
square inch (in ${ }^{2}$ ) & 6.452 & square centimeter \\
square mile (mi ${ }^{2}$ ) & 2.590 & square kilometer \\
\hline
\end{tabular}

Temperature in degrees Celsius $\left({ }^{\circ} \mathrm{C}\right)$ may be converted to degrees Fahrenheit $\left({ }^{\circ} \mathrm{F}\right)$ as follows:

$$
{ }^{\circ} \mathrm{F}=\left(1.8 x^{\circ} \mathrm{C}\right)+32
$$

Temperature in degrees Fahrenheit $\left({ }^{\circ} \mathrm{F}\right)$ may be converted to degrees Celsius $\left({ }^{\circ} \mathrm{C}\right)$ as follows:

$$
{ }^{\circ} \mathrm{C}=\left({ }^{\circ} \mathrm{F}-32\right) / 1.8
$$

Altitude, as used in this report, refers to distance above the vertical datum. 


\section{Conversion Factors, Datums, and Abbreviatons-Continued}

Datums

Vertical coordinate information is referenced to the North American Vertical Datum of 1929

(NAVD 29).

Horizontal coordinate information is referenced to the North American Datum of 1927 (NAD 27).

Abbreviations

\begin{tabular}{ll}
\hline Abbreviation & Definition \\
\hline CRBG & Columbia River Basalt Group \\
DEM & digital elevation model \\
DGER & Division of Geology and Earth Resources \\
DNR & Washington State Department of Natural Resources \\
GIS & Geographic Informaton System \\
GPS & global positioning system \\
NWIS & National Water Information System \\
SOAC & System Operations Advisory Committee \\
TWSA & current available storage in the reservoirs, estimates of \\
& unregulated flow, and other sources that are principally return \\
& flow \\
USGS & U.S. Geological Survey \\
WaDOE & Washington State Department of Ecology \\
WRIA & Washington State Water Resources Inventory Area \\
YN & Yakama Nation \\
\hline
\end{tabular}


This page intentionally left blank. 


\title{
Hydrogeologic Framework of Sedimentary Deposits in Six Structural Basins, Yakima River Basin, Washington
}

\author{
By M.A. Jones, J.J. Vaccaro, and A.M. Watkins
}

\begin{abstract}
The hydrogeologic framework was delineated for the ground-water flow system of the sedimentary deposits in six structural basins in the Yakima River Basin, Washington. The six basins delineated, from north to south are: Roslyn, Kittitas, Selah, Yakima, Toppenish, and Benton. Extent and thicknesses of the hydrogeologic units and total basin sediment thickness were mapped for each basin. Interpretations were based on information from about 4,700 well records using geochemical, geophysical, geologist's or driller's logs, and from the surficial geology and previously constructed maps and well interpretations. The sedimentary deposits were thickest in the Kittitas Basin reaching a depth of greater than 2,000 ft, followed by successively thinner sedimentary deposits in the Selah basin with about 1,900 ft, Yakima Basin with about 1,800 ft, Toppenish Basin with about 1,200 ft, Benton basin with about $870 \mathrm{ft}$ and Roslyn Basin with about $700 \mathrm{ft}$.
\end{abstract}

\section{Introduction}

Surface water in the Yakima River Basin, in south-central Washington (fig. 1) is under adjudication and the amount of surface water available for appropriation is unknown, but there are increasing demands for water for municipal, fisheries, agricultural, industrial, and recreational uses. These demands must be met by ground-water withdrawals and/or by changes in the way water resources are allocated and used. On-going activities in the basin for enhancement of fisheries and obtaining additional water for agriculture may be affected by ground-water withdrawals and by rules implemented under the Endangered Species Act for salmonids that have been either listed or are proposed for listing in the late 1990s. An integrated understanding of the ground-water flow system and its relation to the surface-water resources is needed in order to implement most water-resources management strategies in the basin. In order to obtain this understanding, a study of the Yakima River Basin aquifer system began in June 2000. The study is a cooperative effort of the U.S. Geological Survey (USGS), Bureau of Reclamation (Reclamation), the Yakama Nation (YN), and the Washington State Department of Ecology (WaDOE).

The objectives of the study as a whole are to fully describe the ground-water flow system and its interaction with and relation to surface water, and to integrate this information into a management tool—a numerical model. The conceptual model of the flow system and the results of the study will be used to guide and support actions taken by management agencies with respect to ground-water availability and to provide information to other stakeholders and interested parties. The numerical model will be developed as an integrated tool for short-term to long-term management activities, including the testing of potential management strategies.

The study includes three phases. The first phase includes (1) project planning and coordination, (2) compiling, documenting, and assessing available data, and (3) initial data collection. The second phase consists of data collection to support the following Phase 2 work elements: (1) mapping of hydrogeologic units, (2) estimating ground-water pumpage, (3) developing estimates of ground-water recharge, (4) assessing ground water-surface water interchanges, and (5) constructing maps of ground-water levels. Together, these five elements provide the information needed to describe the ground-water flow system, the conceptual model, and provide the building blocks for the hydrogeologic framework. In the third phase, six structural basin models and one regional model of the ground-water flow system will be constructed in order to integrate the available information. The numerical models will be used to gain a further understanding of the flow system and its relation to surface water, and to test management strategies. The models will be developed and maintained in such a fashion that it will be available and open to others.

The results from selected work elements will be described in a series of reports. The Introduction and Description of Study Area sections of this report are common to all reports. 


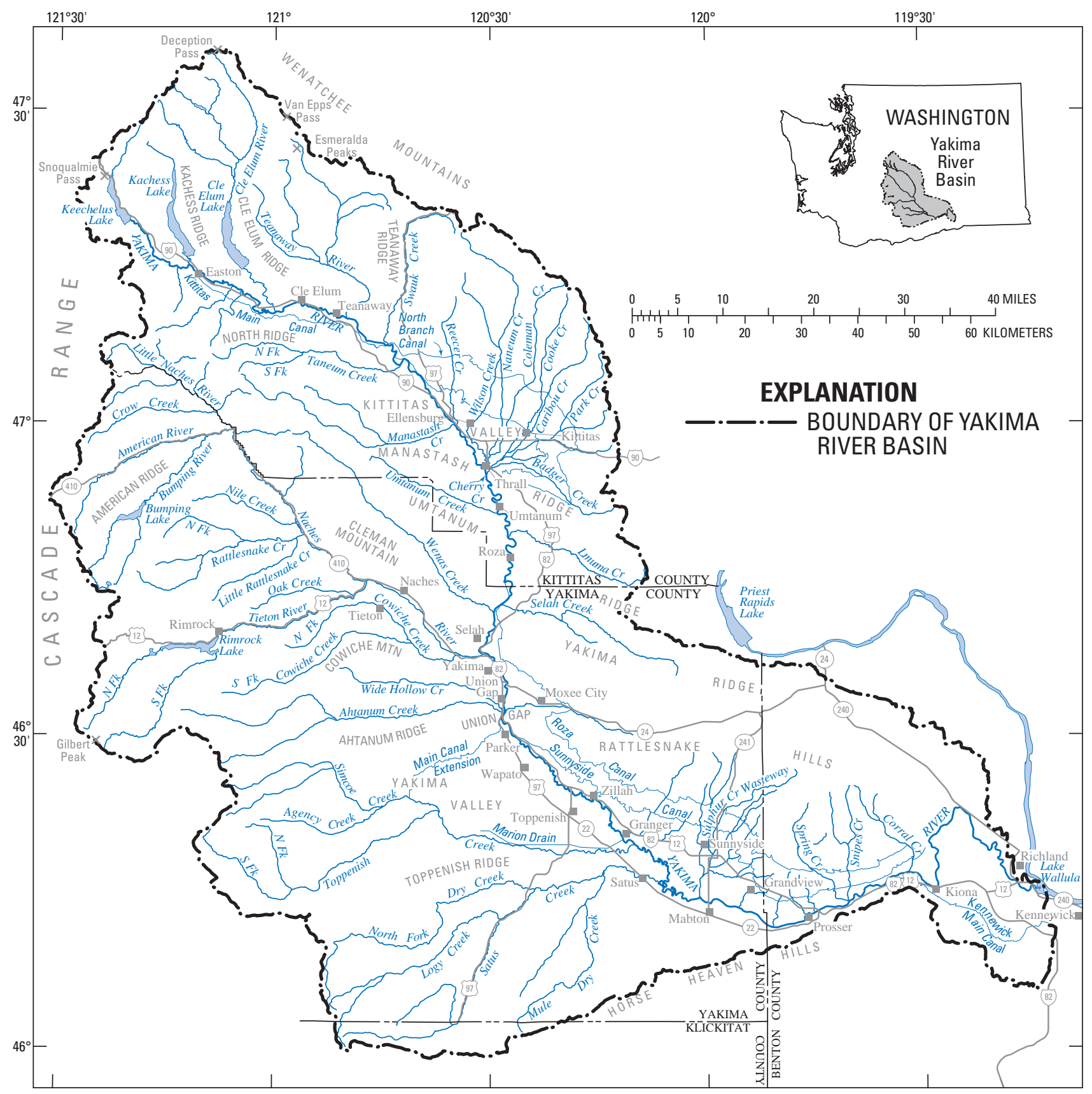

Figure 1. The Yakima River Basin, Washington.

\section{Purpose and Scope}

This report describes the hydrogeologic framework of six structural sedimentary basins within the Yakima River Basin aquifer system. This framework will be used to develop a conceptual model describing local and regional groundwater flow systems. Maps presented in this report provide the hydraulic characteristics and boundaries of the hydrogeologic units located within the Yakima River Basin aquifer system.

\section{Description of Study Area}

The general location and setting of the study area, the development of water resources in the basin, and an overview of the geology are presented to provide a general background for understanding the study area. 


\section{Location and Setting}

The Yakima River Basin aquifer system underlies about $6,200 \mathrm{mi}^{2}$ in south-central Washington (fig. 1). The Yakima River Basin produces a mean annual unregulated streamflow (adjusted for regulation and without diversions or returns) of about 5,600 ft $3 / \mathrm{s}$ (about 4.1 million acre-ft) and a regulated streamflow of about $3,600 \mathrm{ft}^{3} / \mathrm{s}$ (about 2.6 million acre- $\mathrm{ft}$ ). The basin includes three Washington State Water Resource Inventory Areas (WRIA-numbers 37, 38, and 39), part of the Yakama Nation lands, and three ecoregions (Cascades, Eastern Cascades, and Columbia Basin-Omernik, 1987; Cuffney and others, 1997). The basin includes parts of four counties (Klickitat, Kittitas, Yakima, and Benton). Almost all of Yakima County and more than 80 percent of Kittitas County lie within the basin, and about 50 percent of Benton County is in the basin. Less than 1 percent of the basin lies in Klickitat County, principally in an unpopulated upland area.

The headwaters of the basin are on the upper, humid east slope of the Cascade Range, where the mean annual precipitation is more than $100 \mathrm{in}$. The basin terminates at the confluence of the Yakima and Columbia Rivers in the low-lying, arid part of the basin, which receives about 6 in of precipitation per year. Altitudes in the basin range from 400 to nearly $8,000 \mathrm{ft}$. There are eight major rivers and numerous smaller streams tributary to the Yakima River (fig. 1); the largest tributary is the Naches River. Most of the precipitation in the basin falls during the winter months as snow in the mountains. The mean annual precipitation over the entire basin is about 27 in (about 12,000 ft $3 / \mathrm{s}$ or 8.7 million acre-ft). The spatial pattern of mean annual precipitation resembles the pattern of the basin's highly variable topography. The difference between the mean annual precipitation and mean annual unregulated streamflow is $6,400 \mathrm{ft}^{3} / \mathrm{s}$ (about 4.6 million acre-ft) or about 53 percent of the precipitation is lost to evapotranspiration under natural conditions.

The basin is separated into several broad valleys by large east-west trending anticlinal ridges. The valley floors are flat and slope gently towards the Yakima River. Few perennial tributary streams traverse these valleys. Most of the population and economic activity occurs in these valleys.

Agriculture is the principal economic activity in the basin. The average annual surface-water demand met by the Reclamation project is about 2.5 million acre-ft; there is about 336,000 acre- $\mathrm{ft}$ of additional demand in the lower river basin that is separate from the demand met by the project. Additional surface-water demand that is not met by Reclamation occurs in smaller tributaries and on the large rivers; this demand is based on State appropriated water. More than 95 percent of the demand is for irrigation of about 500,000 acres in the low-lying semiarid to arid parts of the basin (fig. 2). The demand is partially met by storage of nearly 1.1 million acre- $\mathrm{ft}$ of water in five Reclamation reservoirs. The major management point for Reclamation is at the Yakima River near Parker streamflow gaging station. Just upstream of this site, at Union Gap, is the location that is considered the dividing line between the upper (mean annual precipitation of 7 to $125 \mathrm{in}$ ) and lower (mean annual precipitation of 6 to 45 in) parts of the Yakima River Basin. About 45 percent of the water diverted for irrigation is eventually returned to the river system as surface-water inflows and ground-water discharge, but at varying time-lags (Bureau of Reclamation, 1999). During the low-flow period, these return flows, on average, account for about 75 percent of the streamflow below the Yakima River near Parker streamflow gaging station. Much of the surface-water demand in the basin below Parker is met by these return flows and not by the release of water from the reservoirs. As a result of water use in the basin, the difference between mean annual unregulated and regulated streamflow in the basin is about $2,000 \mathrm{ft}^{3} / \mathrm{s}$, suggesting that some 1.4 million acre-ft of water, or about 17 percent of the precipitation in the basin, is consumptively used-principally by irrigated crops through evapotranspiration.

\section{Development of Water Resources}

Missionaries arrived in the basin in 1848 and established a mission in 1852 on Atanum (now Ahtanum) Creek. They were some of the first non-Indian settlers to use irrigation on a small scale. Miners and cattlemen immigrated to the basin in the 1850s and 1860s, which resulted in a new demand for water. With increased settlement in the mid-1860s, irrigation of the fertile valley bottoms began and the outlying areas were extensively used for stock raising. One of the first known non-Indian irrigation ditches was constructed in 1867 and diverted water from the Naches River (Parker and Storey, 1913; Flaherty, 1975). Private companies later delivered water through canal systems built between 1880 and 1904 for the irrigation of large areas. The development of irrigated agriculture was made more attractive by the construction of the Northern Pacific Railway that reached Yakima in December 1884, which provided a means to transport agricultural goods to markets; two years later, the completion of the railway to the coast provided new and easily accessible markets for agricultural products. The State of Washington was created in 1889, spurring further growth in the basin, especially because the cities of Ellensburg and Yakima were in contention for being the state capital. By 1902 there were about 120,000 acres under mostly surface-water irrigation in the basin (Parker and Storey, 1913; Bureau of Reclamation, 1999). 


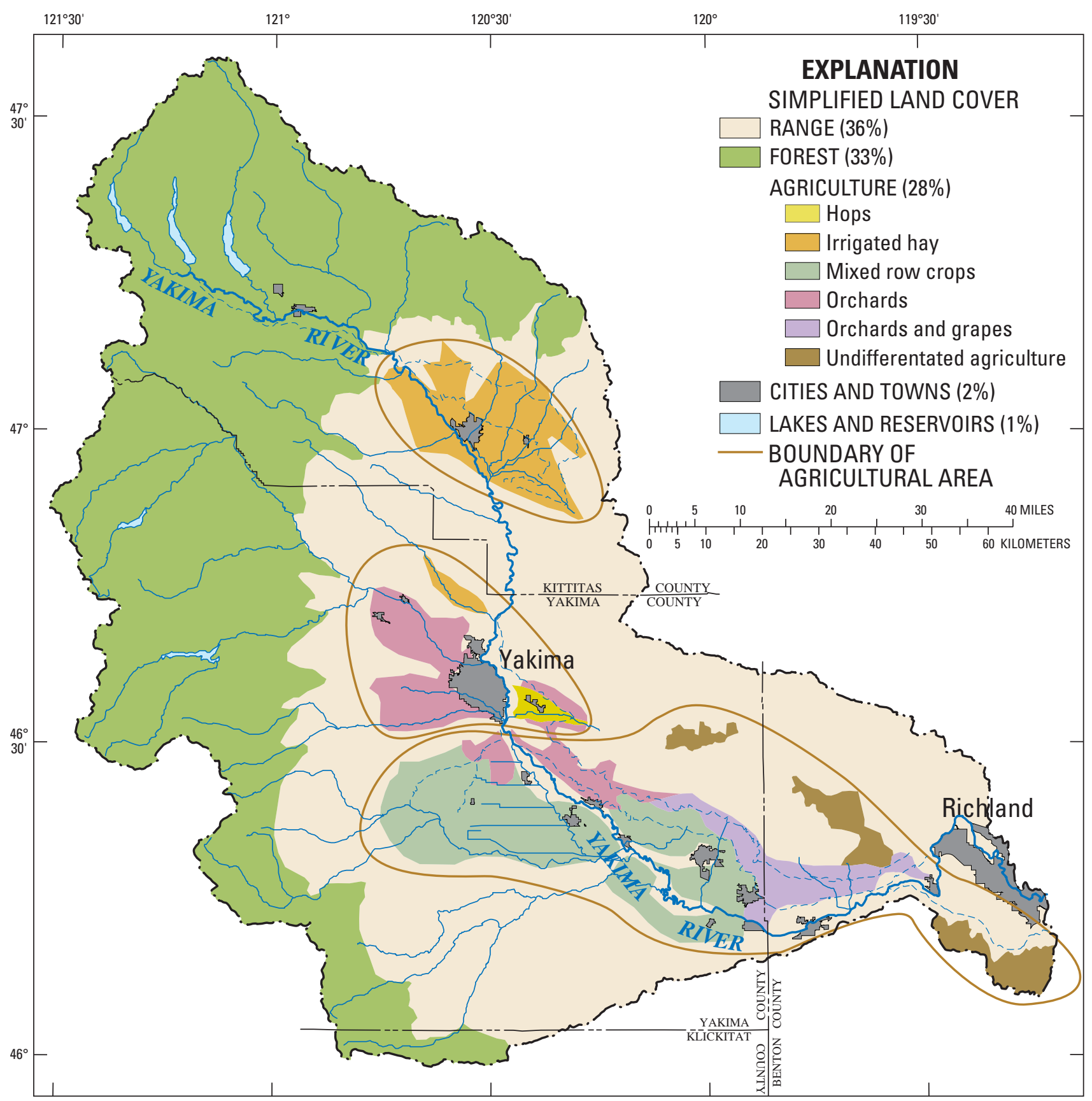

Figure 2. Land use and land cover, Yakima River Basin, Washington, 1999. (From Fuhrer and others, 2004.)

The Federal Reclamation Act was enacted in 1902 to enable the construction of Federal water projects in the western United States in order to expand the development of the West. In 1905, the Washington State Legislature passed the Reclamation Enabling Act and the Yakima Federal Reclamation Project was authorized to construct facilities to irrigate about 500,000 acres. As part of the 1905 authorization and extensions, all forms of further appropriation of unappropriated water in the basin were withdrawn (Parker and Storey, 1913). Six dams were constructed as part of the Yakima Project: Bumping Dam in 1910, Kachess Dam in
1912, Clear Creek Dam in 1914, Keechelus Dam in 1917, Tieton Dam (Rimrock Lake) in 1925, and Cle Elum Dam in 1933. The construction of the dams and other irrigation facilities resulted in an extremely complicated surface-water system (fig. 3). These Federal reservoirs provide water storage to meet irrigation requirements of the major irrigation districts at the time of year when the natural streamflow from unregulated streams can no longer meet demands; this time is referred to as the 'storage control' date. Several of the reservoirs also provide instream flows during the winter for the incubation of salmon eggs in the salmon redds (gravel spawning nests). 

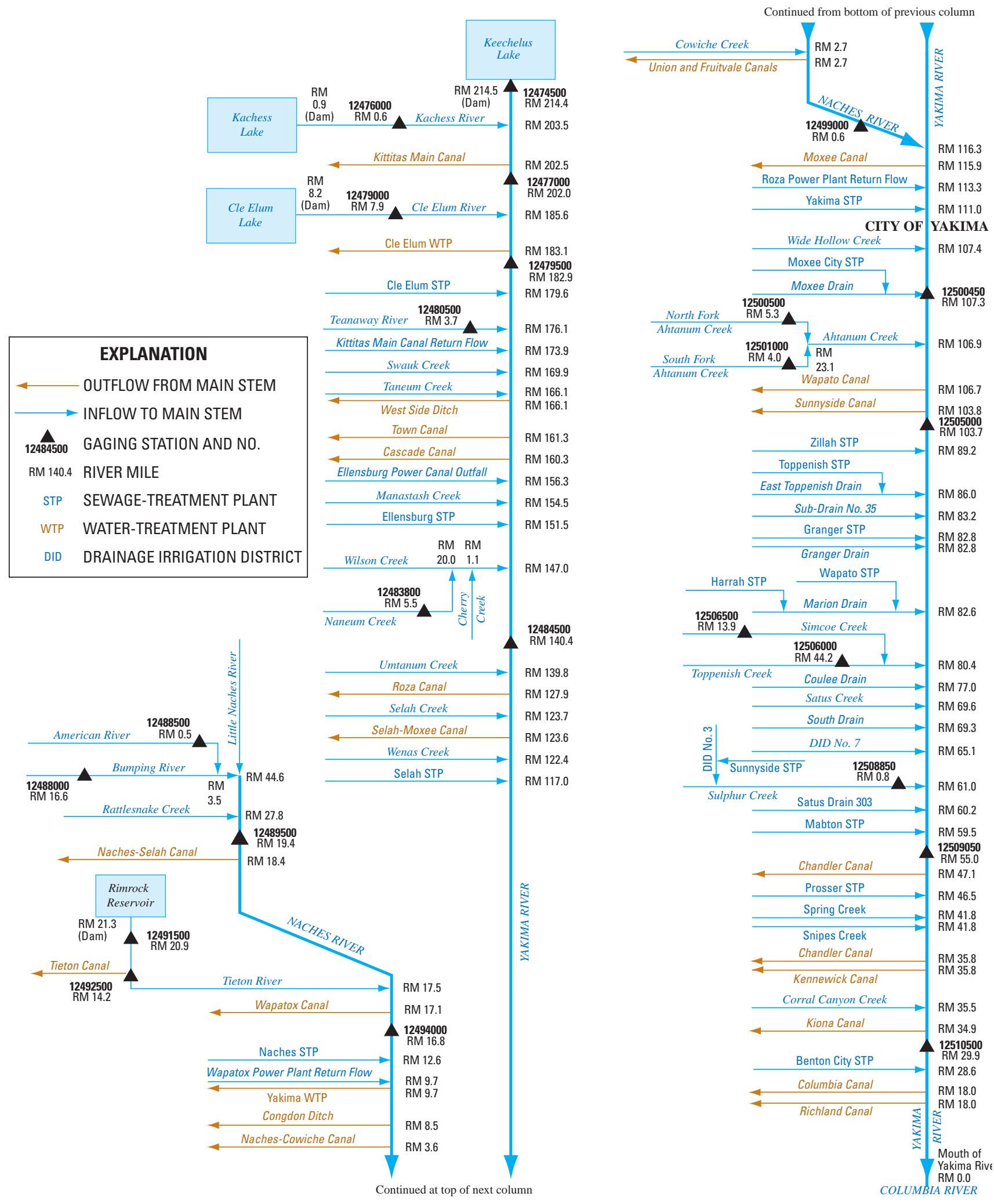

Figure 3. Selected tributaries, diversion canals, return flows, and streamflow-gaging stations, Yakima River Basin, Washington. (From Fuhrer and others, 2004.) 
Hydrogeologic Framework of Sedimentary Deposits in Six Structural Basins, Yakima River Basin, Washington

Legal challenges to water rights resulted in the 1945 Consent Decree (U.S. District Court, 1945) that established the framework of how the Reclamation operates the Yakima Project to meet the water demands. The Decree determined two classes of rights-nonproratable and proratable. When the total water supply available (TWSA-defined as current available storage in the reservoirs, estimates of unregulated flow, and other sources that are principally return flows) is not sufficient to meet both classes of rights, the proratable (junior) rights are decreased according to the quantity of water available defined by the TWSA. This legally mandated method generally performs well in most years, but is dependent on the accuracy of the TWSA estimate. In some years, for example 1977, problems have arisen because of errors in the TWSA estimate (Kratz, 1978; Glantz, 1982). System management also accounts for defined instream flows at selected target points on the river, and for suggested changes in storage releases recommended by the Systems Operations Advisory Committee (SOAC) - the advisory board of fishery biologists representing the different stakeholders (Systems Operations Advisory Committee, 1999).

The drilling of numerous wells for irrigation was spurred by new (post 1945) well-drilling technologies, legal rulings, and the onset of a multi-year dry period in 1977 (Vaccaro, 1995). Population growth in the basin was, and still is, the driving force behind the increased drilling of shallow domestic wells and deeper public water supply wells. Currently, there are more than 20,000 wells in the basin. More than 70 percent of these wells are shallow, 10-250 ft deep, domestic wells. Based on the digital water-rights database provided by WaDOE (R. Dixon, written commun., 2001) and other information there are at least 2,874 active ground-water rights associated with the wells in the basin that can withdraw an annual quantity of about 529,231 acre-ft during dry years. The irrigation rights are for the irrigation of about 129,570 acres. There are about 16,600 ground-water claims in the basin; these claims are for some 270,000 acre-ft of ground water (J. Kirk, written commun., Washington State Department of Ecology, 1998).

A water right claim is a statement of claim to water use that began before the state Water Codes were adopted, and is not covered by a water right permit or certificate. A water right claim does not establish a water right, but only provides documentation of one if it legally exists. Ultimately, the validity of claimed water rights would be determined through general water right adjudications. (Washington State Department of Ecology, 1998).

A ground-water claim means a user claims that they were using ground water continuously, prior to 1945 when the State legislature enacted the Ground Water Code, for a particular use. Previous estimates of pumpage have varied widely and are presented in the report on pumpage (J.J. Vaccaro, U.S. Geological Survey, written commun., 2006).

\section{Overview of the Geology}

The Columbia Plateau has been informally divided into three physiographic subprovinces (Meyers and Price, 1979). The western margin of the Columbia Plateau contains the Yakima Fold Belt subprovince and includes the Yakima River Basin. The Yakima Fold Belt is a highly folded and faulted region and within the study area part, it is underlain by various consolidated rocks, ranging in age from Precambrian to Tertiary, and unconsolidated materials and volcanic rocks of Quaternary age (fig. 4). In the Yakima River Basin, the headwater areas in the Cascade Range include metamorphic, sedimentary, and intrusive and extrusive igneous rocks. The central, eastern, and southwestern parts of the basin are composed of basalt lava flows of the Columbia River Basalt Group (CRBG) with some intercalated sediments that are discontinuous and weakly consolidated. The lowlands are underlain by unconsolidated and weakly consolidated valley-fill composed of glacial, glacio-fluvial, lacustrine, and alluvium deposits that in places exceed a 1,000 ft in thickness (Drost and others, 1990). Wind-blown deposits, called loess, occur locally along the lower valley.

Valley-fill deposits and basalt lava flows are important for ground-water occurrence in the study area. The basalt consists of a series of flows erupted during various stages of the Miocene Age, ranging from 17 to 6 million years ago. Basalt erupted from fissures from the eastern part of the Columbia Plateau and individual flows range in thickness from a few feet to more than $100 \mathrm{ft}$. The total thickness in the central part of the plateau is estimated to be greater than 10,000 ft (Drost and others, 1990) with a maximum thickness of more than $8,000 \mathrm{ft}$ in the study area. Unlike most of the Columbia Plateau, the CRBG in the Yakima Fold Belt is underlain by sedimentary rocks. The valley-fill deposits were eroded from the Cascade Range and from the east-west-trending anticlinal ridges that were formed from the buckling of the basalt sequence during mid- to late-Miocene time. Much of these deposits are part of the Ellensburg Formation. This formation underlies, intercalates, and overlies the basalts along the western edge, and composes most of the thickness of the unconsolidated deposits (informally called the overburden; Drost and others, 1990) in the basinal areas. The basins are narrow to large open synclinal valleys intervening between the numerous anticlinal ridges.

The deposition of a thick, upper sequence of sand, gravel, and some fine-grained material is the result of erosion by glacial ice and transport by meltwater streams. Damming of large lakes by glacial ice during the Pleistocene epoch resulted in the deposition of silt and clay beds in parts of the uplands. When the lakes drained, the fine sediments were exposed and subsequently eroded by wind and deposited over the lower, eastern parts of the study area. Thus, the unconsolidated materials in the basinal areas that are abutting and interbedded with the basalts range from Miocene to Holocene in age. 


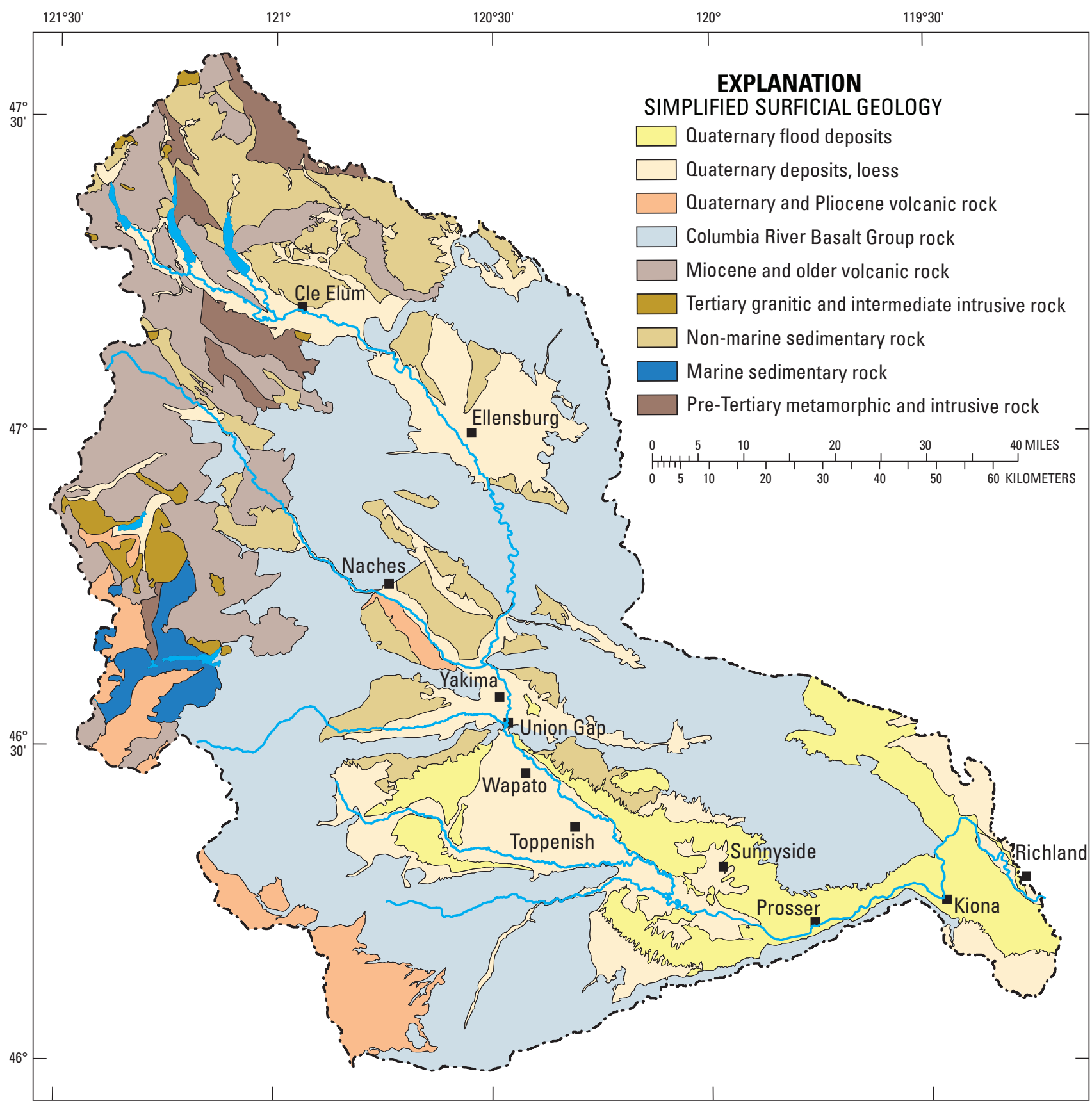

Figure 4. Simplified surficial geology, Yakima River Basin, Washington. (From Fuhrer and others, 1994.) 


\section{Well-Numbering System}

The USGS assigns numbers to wells and springs in Washington that identify their location in a township, range, and section. Well number 20N/15E-26N01 indicates successively, the township (T. 20 N.) and the range (R. 15 E.) north and east of the Willamette baseline and meridian (fig. 5). The first number following the hyphen indicates the section (26) within the township, and the letter following the section number $(\mathrm{N})$ gives the 40 -acre subdivision of the section, as shown above. The number (01) following the letter is the sequence number of the well within the 40 -acre subdivision. An "S" following the sequence number indicates that the site is a spring, a "D1" after the sequence number indicates that the original reported depth of the well has been changed once and successive numbers indicate the number of changes in the well depth. An " $\mathrm{R}$ " following the sequence number indicates the well has been reconditioned. A "P1" or "A" after the sequence number indicates a group of nested piezometers, with successive numbers or letters assigned to each piezometer in the group.

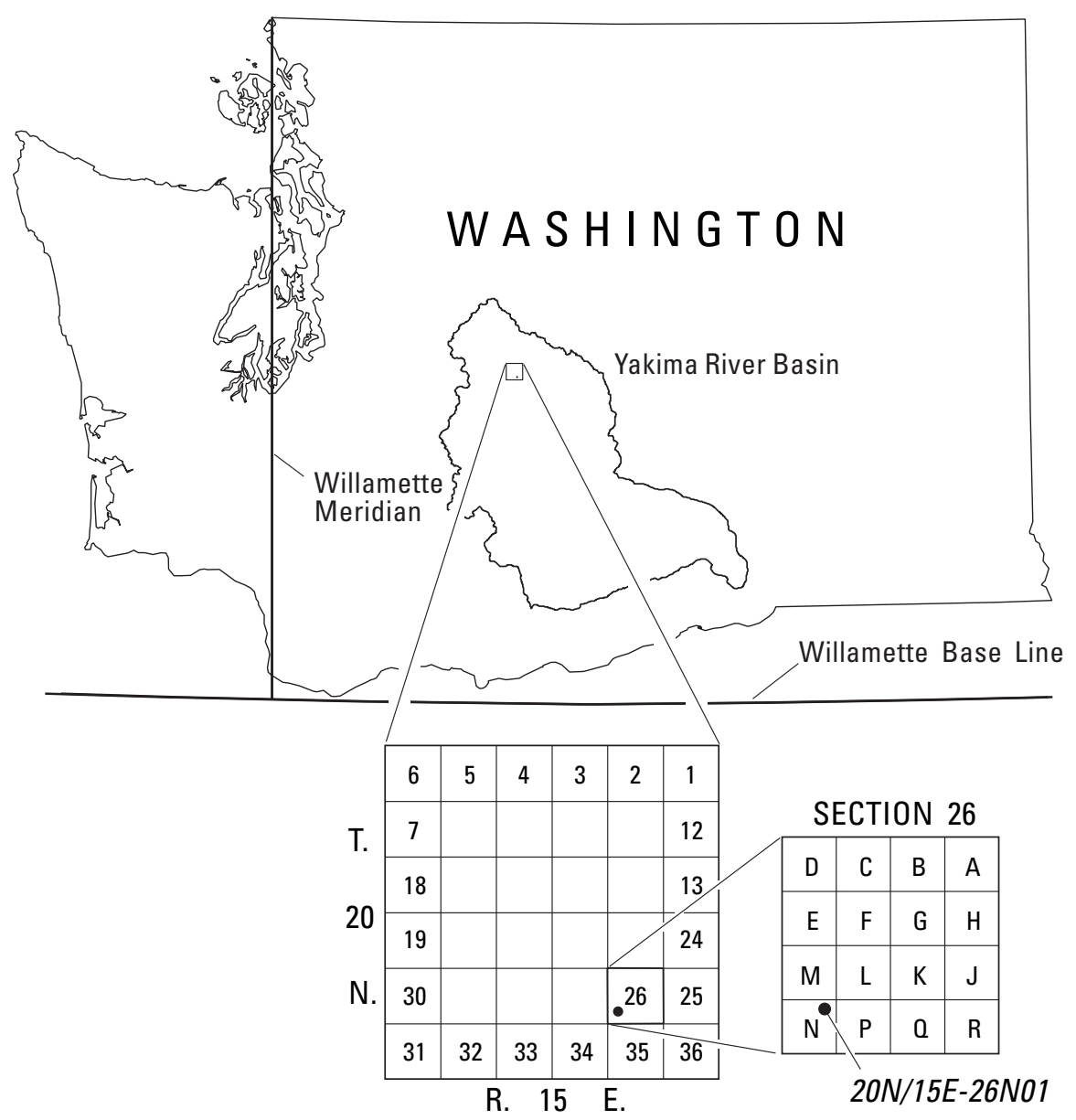

Figure 5. Well-numbering systems used in the State of Washington. 


\section{Methods of Investigation}

Three classes of well information were used to delineate the hydrogeologic framework for the sedimentary deposits in the six basins. The classes include the wells inventoried during this study, wells that were previously inventoried by USGS and WaDOE personnel, and wells that were not inventoried. The latter class of wells were selected to help refine the hydrogeologic framework in strategic areas where available inventoried well data were limited.

The inventory of wells for this study began with the compilation of existing well, piezometer, geophysical, test hole, and geochemical records obtained from files of the USGS, WaDOE, consulting firms, and well owners. Beginning in the spring of 2000, more than 12,000 well records were reviewed; from these records, about 4,700 sites were selected for field inventory. Selections were based on the well owner's or tenant's permission to visit the well, the location and depth of the well, the availability of a driller's log or equivalent, and the ease of access to the well. Priority also was given to wells that were previously inventoried and had water levels measured by the USGS, wells in the WaDOE observation network, and wells that were open to only one hydrogeologic unit.

During the field inventory and water-level measurement period (autumn of 2000, 2001 and spring of 2001, 2002), 2,017 sites were inventoried by USGS, Reclamation, WaDOE, and the YN. Information gathered at all inventoried sites included site location, land-surface altitude, primary use of water, owner's or tenant's comments on water quality, yield, surrounding land-use practices, and any changes in construction details from the original well log. In addition, the depth to water in the wells was measured when possible and, where available, the WaDOE identification tag numbers were recorded on field sheets.

Site locations for inventoried wells were plotted on USGS 1:24,000 scale topographic maps. Latitude and longitude locations were determined using a satellite-based global positioning system (GPS) with a horizontal accuracy of $\pm 10 \mathrm{ft}$, or from field maps compiled during the inventory. Altitudes of the land surface at each well were interpolated from the topographic maps based either on the GPS or the mapped location of the well. Altitude accuracy generally was between 5 and $20 \mathrm{ft}$. Information collected during the inventory was entered into the USGS National Water Information System (NWIS) database.

The goal of the inventory was to obtain an even areal distribution of the wells in the study area. However, this was not possible for the entire study area because of time constraints and a lack of wells in less populated areas. Therefore, wells selected in this study also include wells that had been previously inventoried and wells that were not inventoried.
Wells selected to help define the hydrogeologic framework that had been previously inventoried by USGS and WaDOE, but were not re-inventoried during this study, had been field inventoried in a similar manner as the field inventory described above. The major difference between the field inventory in this study and in the previous field inventories was that fewer wells were inventoried using a GPS and the well locations were plotted on topographic maps compiled in the field. The resulting latitude and longitude values for the wells were calculated from these topographic field maps. Locations of these field checked wells generally are accurate within a radius of several hundred feet of their actual location.

Wells selected to help define the hydrogeologic framework that were not inventoried were plotted based on an available address that matched the driller's reported township, range, section, and quarter-quarter section. If the address did not match, the well was plotted in the center of the 40-acre driller's reported quarter-quarter section. Locations of these non-field-checked wells are generally accurate within a radius of $0.25 \mathrm{mi}$ of their actual location.

The surficial geology for the Yakima River Basin was simplified from twelve 1:100,000 digital quadrangle maps available from Washington State Department of Natural Resources (DNR) Division of Geology and Earth Resources (DGER). These included the quadrangles for: Skykomish, Chelan, Snoqulamie, Banks Lake, Wenatchee, Mount Rainier, Yakima, Priest Rapids, Mount Adams, Toppenish, Richland, and Goldendale. In addition, published paper maps and detailed descriptions of the geologic units were acquired from DGER and the USGS to help in simplification and grouping of the geologic units.

The 12 maps were merged into 1 digital surficial geologic map; no attempt was made to reconcile matching of the surficial geologic units across mapped quadrangle boundaries. The surficial geologic units generally were then grouped by age (Quaternary, Tertiary, Mesozoic, Paleozoic, and preCambrian), and by type of deposit. Some deposits were grouped by formation, others were grouped by igneous phase. The CRBG was already mapped into the Grande Ronde, Wanapum, and Saddle Mountain Formations for most of the study area. Where it was mapped as a formation member, it was grouped into the associated CRBG formation. This process resulted in the original 512 surficial units being grouped into 64 units.

The resulting simplified surficial geology was used to assist in delineating the extent of six structural sedimentary basins and to delineate the hydrogeologic framework of each of these basins. The delineated basins are from north to south, the Roslyn, Kittitas, Selah (also referred to as the Selah-Wenas), Yakima (also referred to as the AhtanumMoxee), Toppenish, and Benton Basins (fig. 6). The geologic structure in the Yakima River Basin clearly defines most of the sedimentary basins (fig. 7). 


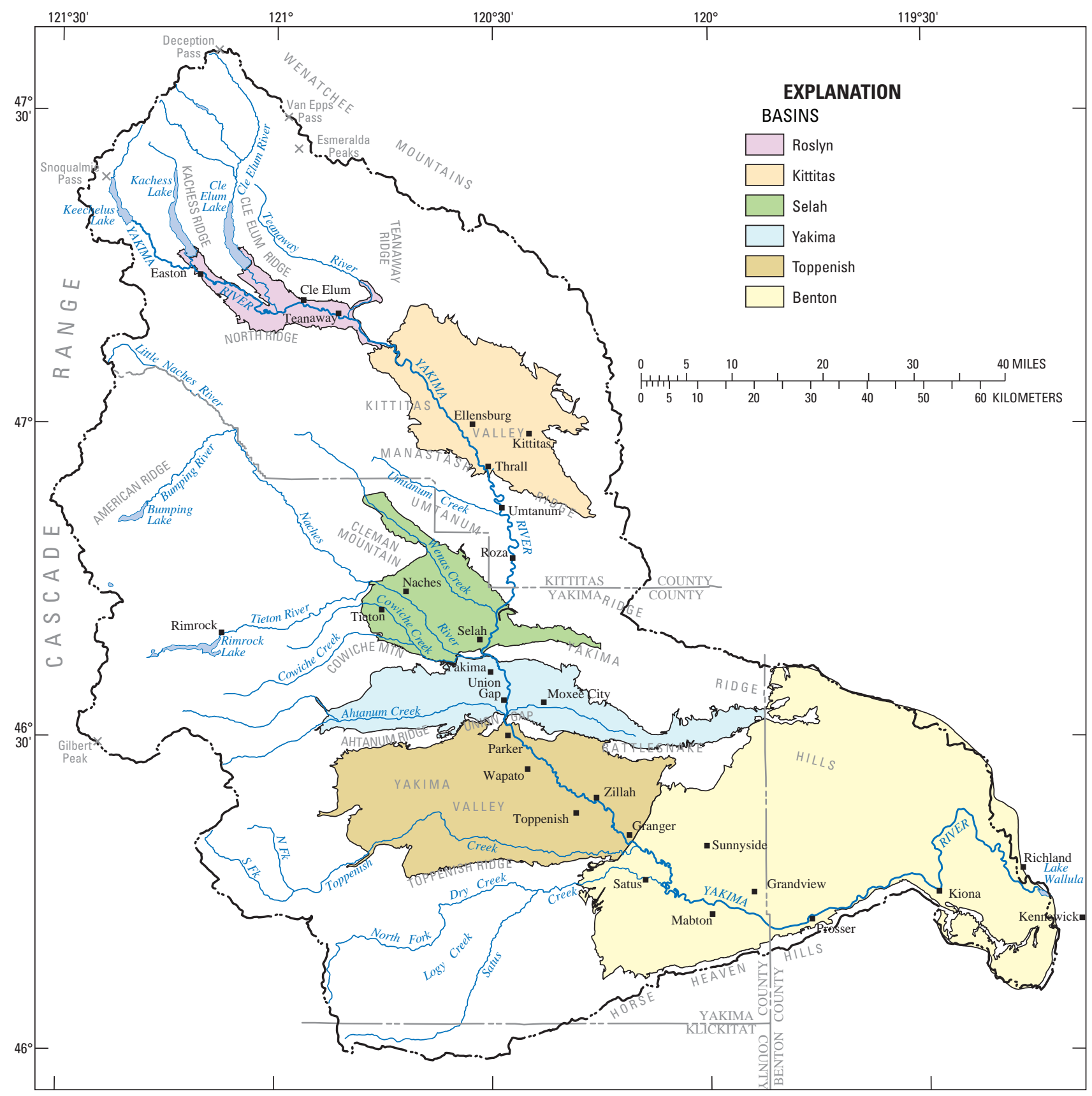

Figure 6. Location of six sedimentary basins, Yakima River Basin, Washington.

Thickness and extent maps of the hydrogeologic units in the basin-fill deposits were constructed for the six basins based on: (1) the simplified surficial geology, (2) well interpretations from previous investigations and maps, (3) unit interpretations from sections constructed in each basin, and (4) unit interpretations made from well information collected from about 4,700 wells. Available data for the six basins were first integrated into a three-dimensional (3D) representation of the hydrogeologic framework for each basin. The deposits in the basins were then divided and mapped into hydrogeologic units and a total thickness of the basin-fill deposits. Except for the Roslyn Basin, the total thickness for each basin was based on the thickness of the deposits to the first encounter of the CBRG. The total thickness of the basin-fill deposits for the Roslyn Basin was based on the first encounter of the consolidated continental sedimentary bedrock deposits. The accuracy of the delineations of the hydrogeologic units are primarily dependent on the methods of identification. 


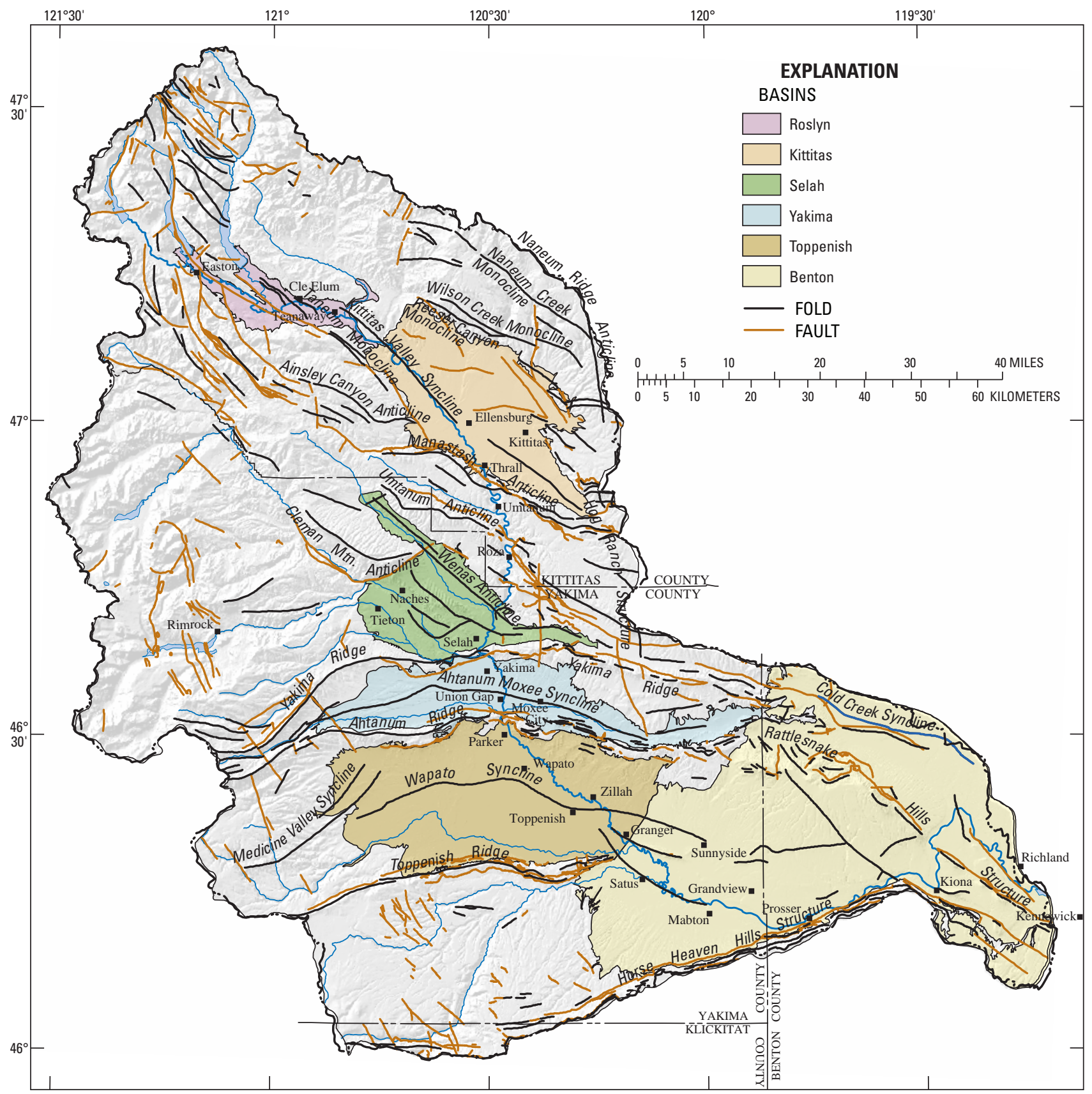

Figure 7. Structure delineating six sedimentary basins, Yakima River Basin, Washington.

The delineations made from a geologists' lithologic log or geophysical log are relatively accurate, but vary according to the complexity of the geology. The delineations made from drillers' logs are the least accurate, particularly in structurally complex areas.

In addition, previously delineated and mapped hydrogeologic units were incorporated as part of this study, in particular for the Toppenish and Benton Basins. Mapping of hydrogeologic units in parts of the Yakima River Basin was previously completed by Drost and Whiteman (1986, and 1990), Drost and others (1997), Newell Campbell, (unpub. maps produced for Yakama Nation, 2001), and Reidel and Thorn, Battelle Corp. (written commun., 2003 and 2005). How this previous work was incorporated is described in more detail in the discussions of the hydrogeologic framework for the applicable basins. 
All data types were entered into a Geographic Information System (GIS) software program in order to construct a gridded, digital hydrogeologic framework for each basin using a 10-meter (m) cell size. Data types for each basin included a digital elevation model (DEM), the simplified surficial geology, previously constructed hydrogeologic unit contour maps (where available), mapped extents of hydrogeologic units, well-log point values of the tops and thicknesses of a hydrogeologic unit, and the interpretations from sections that were constructed for each basin.

In developing the 3D framework, the original data interpretations were honored as much as possible. Thus, the calculated top and thickness cell values and/or mapped contours for the hydrogeologic units were compared to the original well, section interpretations, and/or mapped contour data and adjusted to more accurately reflect the original interpretations. The areas where the calculated units are less accurate are in areas of (1) data gaps, (2) where the surficial geology changes abruptly, (3) structural complexity over short distances, and (4) where the well locations are less accurate and where unit contour intervals were more generalized. However, most discrepancies were reconciled through the use of a $10-\mathrm{m}$ scale during the 3D framework construction.

\section{Hydrogeologic Framework}

This section describes the hydrogeologic framework, which defines the physical, lithologic, and hydrologic characteristics of the hydrogeologic units that compose the ground-water system in the individual basins. An understanding of these characteristics is important in determining the occurrence and availability of ground water within each basin. The ground-water flow system in each sedimentary basin is part of the larger Yakima River Basin aquifer system. In turn, the part of the aquifer system contained by the CRBG is part of the Columbia Plateau regional aquifer system.

The hydrogeologic units vary by basin, and will be discussed separately for each basin. The hydrogeologic units identified in this report do not necessarily correspond to geologic time-stratigraphic deposits. The ground-water flow system within the basin-fill deposits in each basin is generally isolated from other basins but is interconnected with the larger Yakima River Basin aquifer system.

Knowledge of the geologic structure that exists within and surrounds each basin (fig. 7) also assisted in mapping of the hydrogeologic units. The structural setting helps to explain the depositional sequences, thickness variations, and segmentation of the ground-water movement or anomalous water-level distributions within the area. For example, a predominantly fine-grained unit could be vertically offset and juxtaposed with a coarse-grained unit, thereby truncating the lateral ground-water movement along a fault and also offsetting the water-level distribution on either side of the fault. Although these types of questions are not addressed in this report, the structural history has provided information for mapping the hydrogeologic units and should provide additional information related to the ground-water flow system.

\section{Roslyn Basin}

The Roslyn Basin is located southeast of the Kachess and Cle Elum Lakes (figs. 6 and 7) and encompasses an area of about $80 \mathrm{mi}^{2}$. The south-central part of the basin is dissected by two northwest trending faults with their down-thrown sides toward the northeast, and the northeast part of the basin is divided by a series of synclines and anticlines (pl. 1).

The basin-fill deposits consist predominantly of alluvial, lacustrine, and glacial deposits interspersed with Mesozoic metamorphics and Tertiary volcanic deposits. The deposits were divided and mapped into three hydrogeologic unitsUnits 1 through 3 and a total basin thickness. Information from 307 well logs was used to define the units in the Roslyn Basin. This basin has been the least studied for ground-water availability, thus, only 31 percent of the well logs used to identify the hydrogeologic units and basin thickness were field located and most of these were inventoried during this study.

The three hydrogeologic units consist of an upper coarsegrained unit, a clay unit, and a productive gravel unit (pl. 1). Unit 1 consists of the alluvial, lacustrine, and glacial deposits at and near the surface. The thickness of the unit ranges from 0 to $360 \mathrm{ft}$, with a mean and median thickness of $80 \mathrm{ft}$. The altitude of this unit ranges from 1,760 to $3,420 \mathrm{ft}$, with a mean and median altitude of 2,120 and 2,130 ft, respectively. Unit 2 consists predominantly of fine-grained, lacustrine deposits of clay and silt. The extent and thickness of the unit tends to follow the alluvium valley (pl. 1). The thickness of this unit ranges from 0 to $530 \mathrm{ft}$ with a mean and median thickness of 180 and $170 \mathrm{ft}$, respectively. The altitude of this unit ranges from 1,720 to $2,100 \mathrm{ft}$, with a mean and median altitude of 1,910 and $1,890 \mathrm{ft}$, respectively. Unit 3 consists of coarser deposits, mostly sand and gravels. It is less extensive than the other units and occurs in the deeper parts of the alluvial valley (pl. 1). The thickness of Unit 3 ranges from 0 to $240 \mathrm{ft}$ with a mean and median thickness of 60 and $50 \mathrm{ft}$, respectively. The altitude of this unit ranges from 1,330 to $2,000 \mathrm{ft}$ with a mean and median altitude of 1,670 and 1,690 ft, respectively.

The thickness of the basin-fill deposits in the Roslyn Basin is greatest in the central part of the basin in the Yakima alluvial valley (pl. 1). The total thickness of the basin-fill deposits in the Roslyn Basin ranges from 0 to $700 \mathrm{ft}$ with a mean and median thickness of 150 and $110 \mathrm{ft}$, respectively. The altitude of the top of the bedrock units in this basin ranges from 1,190 to $3,330 \mathrm{ft}$, with a mean and median altitude of 1,990 and $2,010 \mathrm{ft}$, respectively. 


\section{Kittitas Basin}

The Kittitas Basin lies within the northeastern part of the Yakima River Basin and encompasses an area of about $270 \mathrm{mi}^{2}$. The basin is bordered on the southwest by the Ainsley Canyon and Manastash Anticlines, on the northeast by the Wilson Creek Monocline, and is bisected by the Kittitas Valley Syncline (fig. 7). The northeastern part of the basin also contains several east-west and northwest trending high-angle faults with the downthrown side generally to the north and northeast. The southwestern part of the basin contains and is bordered by northwest trending strike-slip and thrust faults (pl. 2).

The basin-fill deposits consist predominantly of alluvial, loess, glacial, continental sedimentary, and Ellensburg Formation deposits. The deposits were divided and mapped into three hydrogeologic units-Units 1 through 3 and a total basin thickness. Information from 419 well logs was used to define the units of the Kittitas Basin. Sixty percent of these wells were field located, and 40 percent were not field located but supplied additional information in areas with limited data.

The three hydrogeologic units consist of alluvial, unconsolidated, and consolidated deposits. Unit 1 consists of the alluvial deposits and the delineation of this unit was confined to the Yakima River floodplain (pl. 2). The unit thickness ranges from 0 to $100 \mathrm{ft}$, with a mean and median thickness of 30 and $10 \mathrm{ft}$, respectively. The altitude of this unit ranges from 1,410 to $1,800 \mathrm{ft}$, with a mean and median altitude of 1,530 and $1,520 \mathrm{ft}$, respectively. Unit 2 consists of the unconsolidated deposits, and generally contains the loess, alluvial fan, glacial, terrace, and Thorp gravel deposits present at the surface and beneath Unit 1 (pl. 2). The thickness of this unit ranges from 0 to $790 \mathrm{ft}$, with a mean and median thickness of 180 and $150 \mathrm{ft}$, respectively. The altitude of this unit ranges from 1,370 to $3,890 \mathrm{ft}$, with a mean and median altitude of 1,930 and 1,870 ft, respectively. Unit 3 is present along the syncline that parallels the southwest boundary of the basin (pl. 2). The consolidated deposits of this unit consist of the Ellensburg Formation and similar undefined continental sedimentary deposits. The thickness of Unit 3 ranges from 0 to 2,040 ft, with a mean and median thickness of 600 and $350 \mathrm{ft}$, respectively. The altitude of this unit ranges from 770 to $2,700 \mathrm{ft}$, with a mean and median altitude of 1,540 and $1,520 \mathrm{ft}$, respectively.

The thickness of the basin-fill deposits in the Kittitas Basin is greatest in the south-central part of the basin generally along the Kittitas Valley Syncline (fig. 7 and pl. 2). The total thickness of the basin-fill deposits in the Kittitas Basin ranges from 0 to $2,120 \mathrm{ft}$, with a mean and median thickness of 500 and $270 \mathrm{ft}$, respectively (pl. 2). The altitude of the top of the CRBG within the Kittitas Basin ranges from -540 to $3,610 \mathrm{ft}$, with a mean and median altitude of 780 and 1,600 ft, respectively.

\section{Selah Basin}

The Selah Basin, also referred to as the Selah-Wenas Basin, is located in the central part of the Yakima River Basin and encompasses about $170 \mathrm{mi}^{2}$. The basin is bounded on the northeast by the Manastash and Umtanum Anticlines and bounded on the southwest by the Yakima Ridge structure (figs. 6 and 7). The central part of this basin is dissected by a series of northwest-southeast trending folds (fig. 7).

The basin-fill deposits consist predominantly of alluvial, alluvial fan, loess, terrace, continental sedimentary, and Ellensburg Formation deposits. The deposits were divided and mapped into three hydrogeologic units-Units 1 through 3 and a total basin thickness (pl. 3). Information from 720 well logs was used to define the units in the Selah Basin. Eighty-nine percent of these wells were field located and 56 percent of the field located wells were located in previous investigations.

The three hydrogeologic units consist of the alluvial, unconsolidated, and consolidated deposits. Unit 1 consists of the alluvial deposits that are contained in the floodplains of Wenas and Cowiche Creeks and the Naches and Yakima Rivers (pl. 3). The thickness of Unit 1 ranges from 0 to $90 \mathrm{ft}$, with a mean and median thickness of $30 \mathrm{ft}$. The altitude of Unit 1 ranges from 1,080 to 2,450 ft, with a mean and median altitude of 1,470 and 1,420 ft, respectively. Unit 2 consists of the unconsolidated deposits, and generally contains the alluvial fan, loess, terrace, and Thorp gravel deposits present as a thin veneer over much of the surface and beneath Unit 1 (pl. 3). The thickness of this unit ranges from 0 to $290 \mathrm{ft}$, with a mean and median thickness of 50 and $40 \mathrm{ft}$, respectively. The altitude of this unit ranges from 1,050 to $2,760 \mathrm{ft}$, with a mean and median altitude of 1,660 and 1,630 ft, respectively. Unit 3 is present throughout most of the basin (pl. 3) and consists of the consolidated deposits, which include the Ellensburg Formation and similar undefined continental sedimentary deposits. The thickness of Unit 3 ranges from 0 to $1,920 \mathrm{ft}$, with a mean and median thickness of 320 and $200 \mathrm{ft}$, respectively. The altitude of the unit ranges from 980 to $3,160 \mathrm{ft}$, with a mean and median altitude of 1,740 and $1,690 \mathrm{ft}$, respectively.

The thickness of the basin-fill deposits in the Selah Basin is greatest in the north-central part of the basin (pl. 3). The thickness of the deposits ranges from 0 to $1,920 \mathrm{ft}$, with a mean and median thickness of 300 and $200 \mathrm{ft}$, respectively. The altitude of the top of the CRBG in the Selah Basin ranges from -300 to $3,100 \mathrm{ft}$, with a mean and median altitude of 1,460 and $1,470 \mathrm{ft}$, respectively. 


\section{Yakima Basin}

The Yakima Basin, also referred to as the AhtanumMoxee Basin, is a long narrow east-west trending basin in the central part of the Yakima River Basin and encompasses an area of about $230 \mathrm{mi}^{2}$. The basin is bounded on the north by the Yakima Ridge, on the south by the Ahtanum Ridge, and is bisected by the Ahtanum-Moxee Syncline (figs. 6 and 7).

The basin-fill deposits consist predominantly of alluvial, alluvial fan, loess, continental sedimentary, and Ellensburg Formation deposits. The deposits were divided and mapped into three hydrogeologic units-Units 1 through 3 and a total basin thickness. Information from 995 well logs was used to define the units in the Yakima Basin. Ninety-nine percent of the wells were field located and 51 percent of these wells were located in previous investigations.

The three hydrogeologic units consist of the alluvial, unconsolidated, and consolidated deposits. Unit 1 consists of the alluvial deposits that are contained in the floodplains of Ahtanum Creek and the Yakima River (pl. 4). The thickness of Unit 1 ranges from 0 to $120 \mathrm{ft}$, with a mean and median thickness of $20 \mathrm{ft}$. The altitude of this unit ranges from 940 to $2,780 \mathrm{ft}$, with a mean and median altitude of 1,270 and $1,180 \mathrm{ft}$, respectively. Unit 2 consists of the unconsolidated deposits, which include the alluvial fan, loess, terrace, and Thorp gravel deposits. Unit 2 generally is present at the surface and beneath Unit 1 (pl. 4). The thickness of Unit 2 ranges from 0 to $350 \mathrm{ft}$, with a mean and median thickness of 90 and $80 \mathrm{ft}$, respectively. The altitude of this unit ranges from 910 to $2,940 \mathrm{ft}$, with a mean and median altitude of 1,480 and $1,460 \mathrm{ft}$, respectively. Unit 3 is present throughout most of the basin with the general exception of its western tip (pl. 4). Unit 3 consists of the consolidated deposits, principally the Ellensburg Formation and similar undefined continental sedimentary deposits. The thickness of Unit 3 ranges from 0 to $1,840 \mathrm{ft}$ with a mean and median thickness of 510 and $450 \mathrm{ft}$, respectively. The altitude of this unit ranges from 760 to $2,780 \mathrm{ft}$, with a mean and median altitude of 1,330 and $1,320 \mathrm{ft}$, respectively.

The thickness of the basin-fill deposits in the Yakima Basin is greatest in the northwestern part of the basin (pl. 4). Its thickness ranges from 0 to $1,840 \mathrm{ft}$, with a mean and median thickness of 530 and $410 \mathrm{ft}$, respectively. The altitude of the top of the CRBG in the Yakima Basin ranges from -510 to $2,900 \mathrm{ft}$, with a mean and median altitude of 980 and $1,840 \mathrm{ft}$, respectively.

\section{Toppenish Basin}

The Toppenish Basin lies in the south-central part of the Yakima River Basin and encompasses an area of about $440 \mathrm{mi}^{2}$. The basin is bordered on the north by the Ahtanum
Ridge, on the south by the Toppenish Ridge, and bisected by the Wapato Syncline (fig. 7). The eastern boundary of this basin abuts the Benton Basin (figs. 6 and 7).

The basin-fill deposits consist predominantly of alluvial, alluvial fan, loess, terrace, continental sedimentary, Touchet, and Ellensburg Formation deposits. The deposits in this basin were divided and mapped into hydrogeologic units-Units 1 through 5 and a total basin thickness. The hydrogeologic unit delineations were modified from contour maps constructed by Campbell (unpub. maps produced for Yakama Nation, 2001). To derive the modified contour maps, a total basin thickness map was constructed first based on information from 1,104 well $\log$ s of which 210 well logs fully penetrated the basin thickness (pl. 5). Ninety-seven percent of the well logs used were field located. The thickness map was then subtracted from the DEM to obtain a map of the top of the CRBG. This map was then compared to the top of the CRBG map compiled by Campbell (unpub. maps produced for Yakama Nation, 2001). The maps were a close match in both the shape of the contours and the contour values. Small differences were predominantly due to newer maps of the surficial geology and the extent that was based on our criteria that the depth of the basin-fill deposits was defined as contact with the first basalt. The contour maps for the units were then digitized and modified based on the updated surficial geology and on the occurrence of the first basalt contact.

The five hydrogeologic units consist of fine-grained and coarse-grained unconsolidated deposits, consolidated deposits, top of the Rattlesnake Ridge unit, and base of the Rattlesnake Ridge unit. Unit 1 consists of fine-grained unconsolidated surficial deposits that include Touchet, terrace, loess, and some alluvial deposits (pl. 5). The thickness of Unit 1 ranges from 0 to $80 \mathrm{ft}$, with a mean and median thickness of $10 \mathrm{ft}$. The altitude of this unit ranges from 690 to 2,030 ft, with a mean and median altitude of 910 and $860 \mathrm{ft}$, respectively. Unit 2 consists predominantly of coarse-grained unconsolidated deposits. The thickness of Unit 2 ranges from 0 to $270 \mathrm{ft}$, with a mean and median thickness of 90 and $80 \mathrm{ft}$, respectively. The altitude of this unit ranges from 660 to 2,310 ft, with a mean and median altitude of 930 , and $850 \mathrm{ft}$, respectively. Unit 3 is present throughout most of the basin (pl. 5). It consists predominantly of the consolidated deposits of the upper Ellensburg Formation and similar undefined continental sedimentary deposits. The thickness of Unit 3 ranges from 0 to $970 \mathrm{ft}$, with a mean and median thickness of 350 and $320 \mathrm{ft}$, respectively. The altitude of this unit ranges from 510 to $2,300 \mathrm{ft}$, with a mean and median altitude of 900 and $820 \mathrm{ft}$, respectively. Unit 4 is present in the central part of the basin (pl. 5), and consists of fine-grained deposits. This unit is referred to as the top of the Rattlesnake Ridge unit of the Ellensburg Formation and the "Blue Clay" layer by Campbell (unpub. maps produced for Yakama Nation, 2001). The 
thickness of Unit 4 ranges from 0 to $520 \mathrm{ft}$, with a mean and median thickness of 170 and $140 \mathrm{ft}$, respectively. The altitude of this unit ranges from -350 to $1,130 \mathrm{ft}$, with a mean and median altitude of 320 and $330 \mathrm{ft}$, respectively. Unit 5 which has an extent similar to Unit 4 (pl. 5) consists predominantly of coarse-grained gravels. This unit is referred to as the base of Rattlesnake Ridge unit of the Ellensburg Formation by Campbell (Tom Ring, Yakama Nation, written commun., 2001). The thickness of Unit 5 ranges from 0 to $140 \mathrm{ft}$, with a mean and median thickness of $20 \mathrm{ft}$. The altitude of this unit ranges from -400 to $1,020 \mathrm{ft}$, with a mean and median altitude of $130 \mathrm{ft}$.

The thickness of the basin-fill deposits in the Toppenish Basin is greatest in the central-southeastern part of the basin (pl. 5). The thickness of the basin-fill deposits ranges from 0 to $1,210 \mathrm{ft}$, with a mean and median thickness of $550 \mathrm{ft}$. The altitude of the top of the CRBG in the Toppenish Basin ranges from -410 to $2,290 \mathrm{ft}$, with a mean and median altitude of 450 and $380 \mathrm{ft}$, respectively.

\section{Benton Basin}

The Benton Basin lies in the southeastern part of the Yakima River Basin. It is the largest of the six basins encompassing an area of about 1,020 $\mathrm{mi}^{2}$. The western boundary of the Benton Basin abuts the eastern boundary of the Toppenish Basin and a small section of the Yakima Basin (figs. 6 and 7). The southern boundary is bordered by the Horse Heaven Hills structure and the northeastern boundary generally follows the northern flank of the Cold Creek Syncline (figs. 6 and 7). The basin is dissected with numerous faults and folds surrounding the Rattlesnake Hills structure in the eastern part of the basin (fig. 7 and pl. 6). The western part of the basin is dissected by the Wapato Syncline and several unnamed folds that lie within the broad flat plain that encompasses the Yakima River floodplain (fig. 7 and pl. 6). Sediment deposits are thickest on the northeastern side of the Rattlesnake Hills structure, which separates the sediment deposits on the northeastern side from those on the southwestern side.

The basin-fill deposits consist of loess, alluvial fan, dune sand, alluvial, terrace, continental sedimentary, and Ellensburg Formation deposits. The deposits for the entire Benton Basin were divided and mapped into two hydrogeologic unitsUnits 1 and 2 and a total basin thickness. Information from 1,141 well $\operatorname{logs}$ was used to define the units of the Benton Basin. All of these wells were field located. Sixty-five percent of the wells were field located during this study and 35 percent were located in previous investigations.

The two hydrogeologic units consist of unconsolidated and consolidated deposits. Unit 1 consists of the unconsolidated deposits that generally consist of the alluvial, alluvial fan, loess, terrace, dune sand, Touchet, Missoula flood and Ringold Formation deposits (pl. 6, sheet 1 and sheet 2). The thickness of Unit 1 ranges from 0 to $870 \mathrm{ft}$, with a mean and median thickness of 120 and $70 \mathrm{ft}$, respectively. The altitude of this unit ranges from 300 to $3,620 \mathrm{ft}$, with a mean and median altitude of 990 and $830 \mathrm{ft}$, respectively. The unconsolidated basin-fill deposits generally are less than $400 \mathrm{ft}$ throughout most of the basin except in the area northeast of the Rattlesnake Hills structure, where thicknesses exceed $800 \mathrm{ft}$ (pl. 6, sheet 2).

Additional information incorporated from previous studies (Drost and others, 1997; Reidel and Thorn, Battelle, written commun., 2003 and 2005) enabled the unconsolidated unit in the east-northeast area of the basin to be divided into six subunits (figs. 8A through 8F). Subunit 1 consists of the fine-grained Touchet and similar deposits present at the surface. The thickness of subunit 1 ranges from 0 to about $300 \mathrm{ft}$ (fig. 8A). Subunit 2 consists of the coarse-grained Pasco gravels and similar deposits present at the surface and beneath subunit 1 . The thickness of subunit 2 ranges from 0 to about $100 \mathrm{ft}$ (fig. 8B). Subunit 3 is of limited extent and consists of the fine-grained deposits of the upper Ringold Formation present beneath Subunit 2. The thickness of subunit 3 ranges from 0 to about $50 \mathrm{ft}$ (fig. 8C). Subunit 4, present throughout most of the northeastern area of the Benton Basin, consists of the coarse-grained deposits of the middle Ringold Formation. The thickness of subunit 4 ranges from 0 to about $400 \mathrm{ft}$ (fig. 8D). Subunit 5, also present throughout most of the northeastern area of the Benton Basin, consists of the fine-grained deposits of the lower Ringold Formation. The thickness of subunit 5 ranges from 0 to about $250 \mathrm{ft}$ (fig. $8 \mathrm{E}$ ). Subunit 6 generally is present beneath Subunit 5, and consists of the coarse-grained basal Ringold Formation. The thickness of Subunit 6 ranges from 0 to about $200 \mathrm{ft}$ (fig. 8F).

Unit 2 is mainly present in the southwestern part of the Benton Basin (pl. 6, sheet 2). The consolidated deposits of this unit include the Ellensburg Formation and similar undefined continental sedimentary deposits. The thickness of Unit 2 ranges from 0 to $680 \mathrm{ft}$, with a mean and median thickness of 100 and $60 \mathrm{ft}$, respectively. The altitude of this unit ranges from 370 to $3,400 \mathrm{ft}$, with a mean and median altitude of 890 and 790 , respectively.

The basin-fill deposits of the Benton Basin are thickest to the west where the basin abuts the Toppenish Basin and in the northeastern area of the basin (pl. 6, sheet 2). The thickness of the basin-fill deposits in the Benton Basin ranges from 0 to $870 \mathrm{ft}$, with a mean and median thickness of 120 and $60 \mathrm{ft}$, respectively. The altitude of the top of the CRBG in the Benton Basin ranges from -300 to $3,630 \mathrm{ft}$, with a mean and median altitude of 960 and $800 \mathrm{ft}$, respectively. 


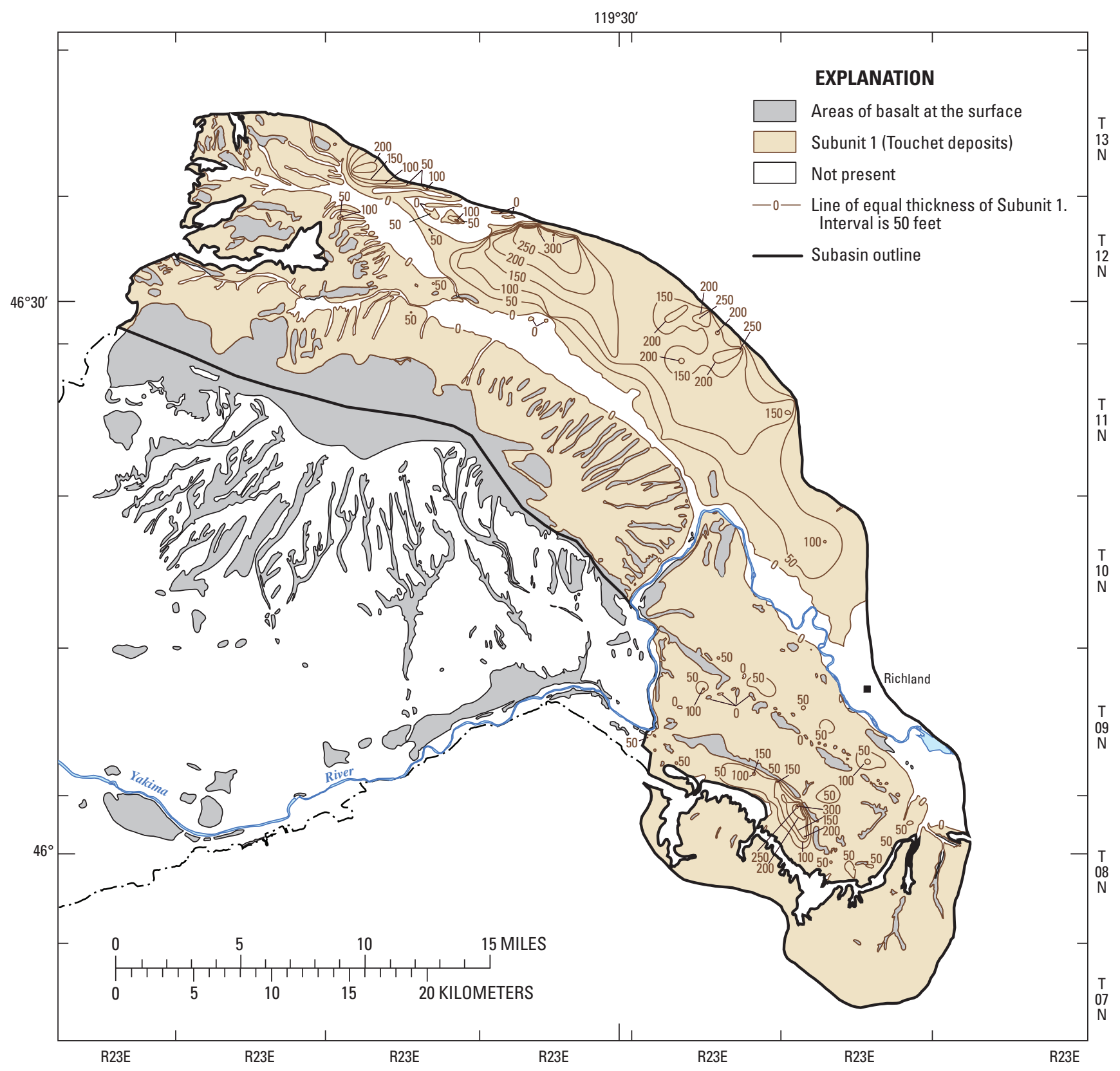

A. Subunit 1 - Fine-grained Touchet and similar deposits

Figure 8. Thickness of subunits 1-6 in northeastern Benton Basin, Yakima River Basin, Washington. 


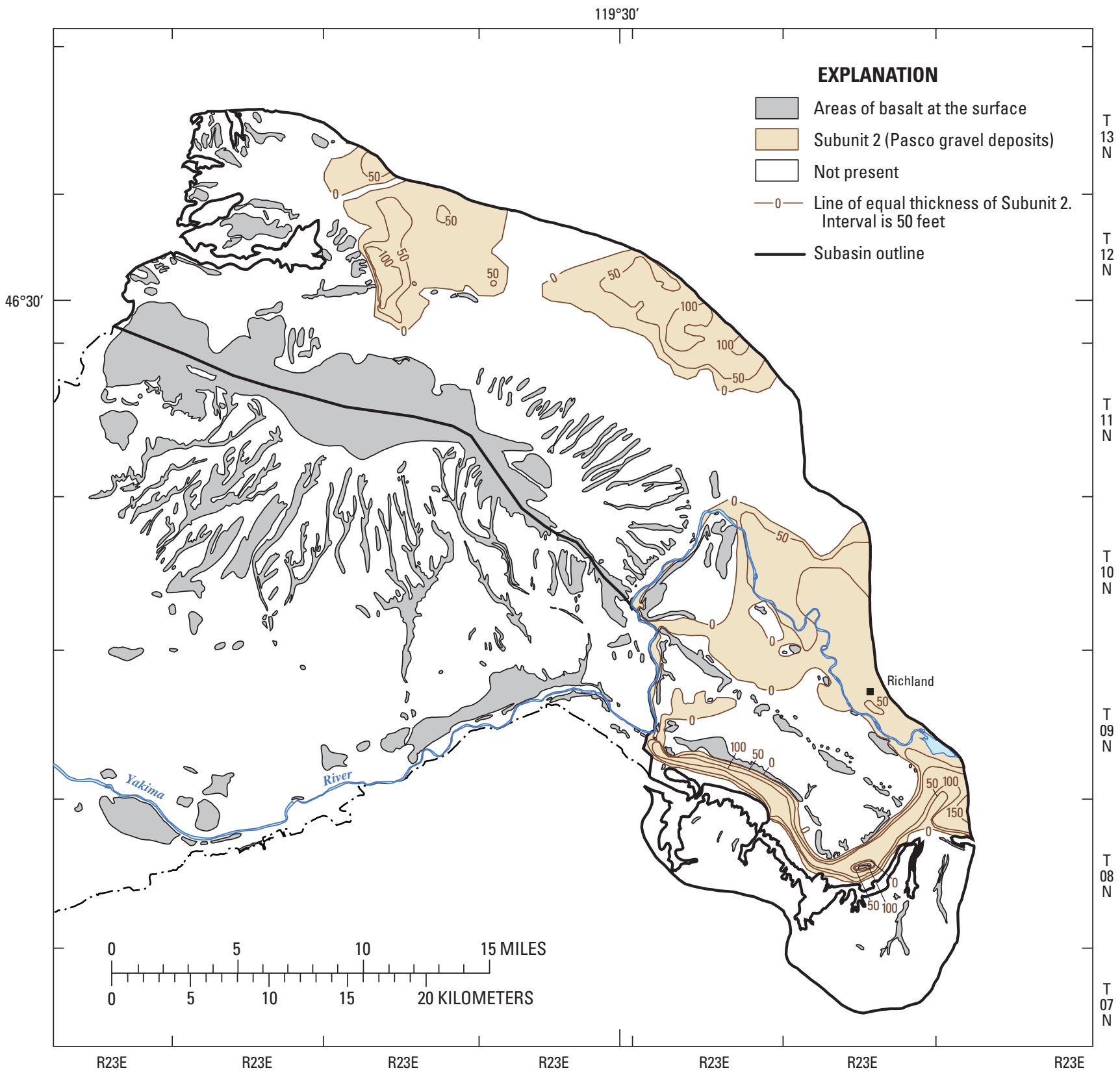

B. Subunit 2 - Coarse-grained Pasco gravels and similar deposits

Figure 8. - Continued. 


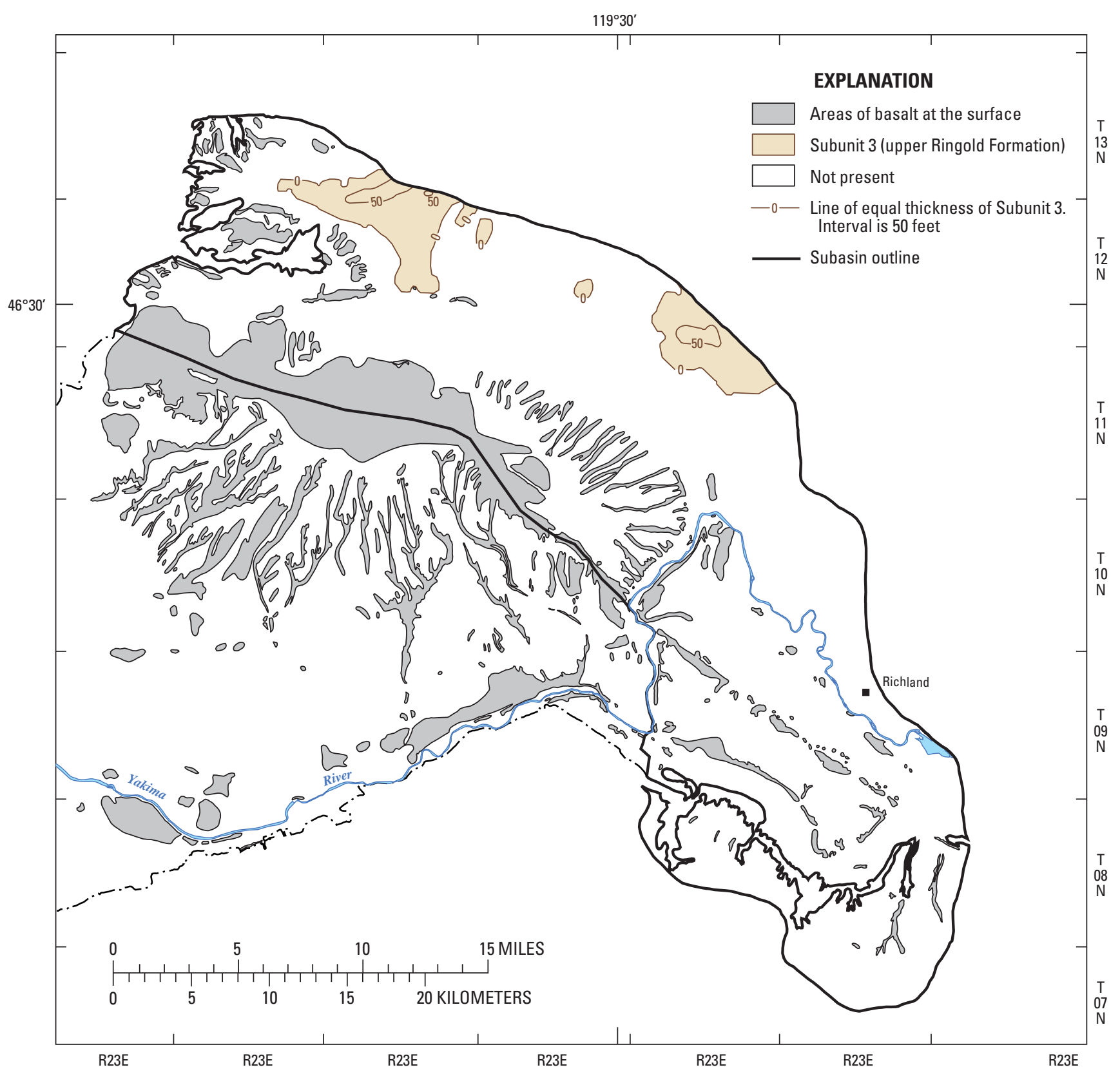

C. Subunit 3 - Fine-grained deposits of the upper Ringold Formation

Figure 8.-Continued. 


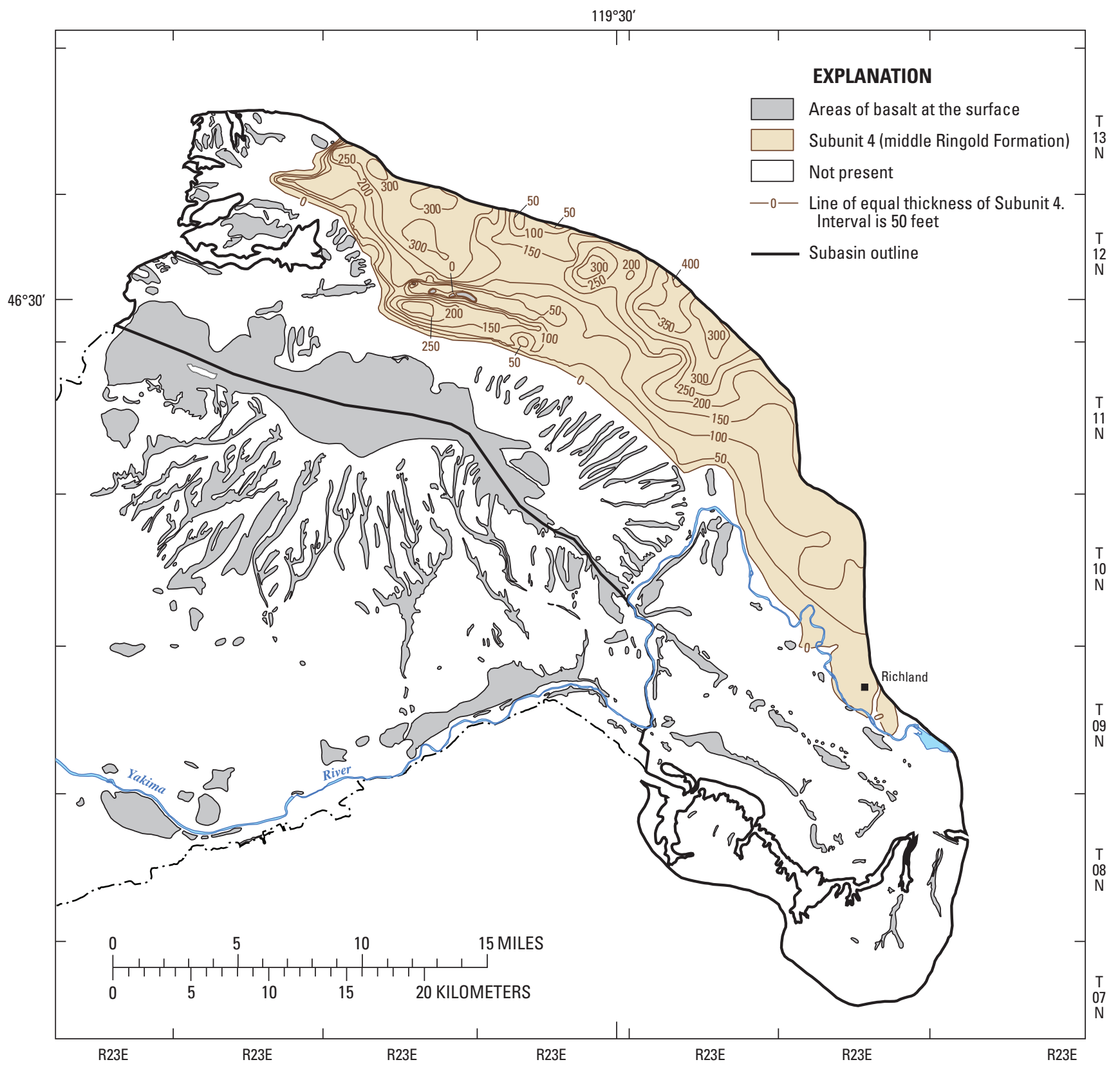

D. Subunit 4 - Coarse-grained deposits of the middle Ringold Formation

Figure 8.-Continued. 


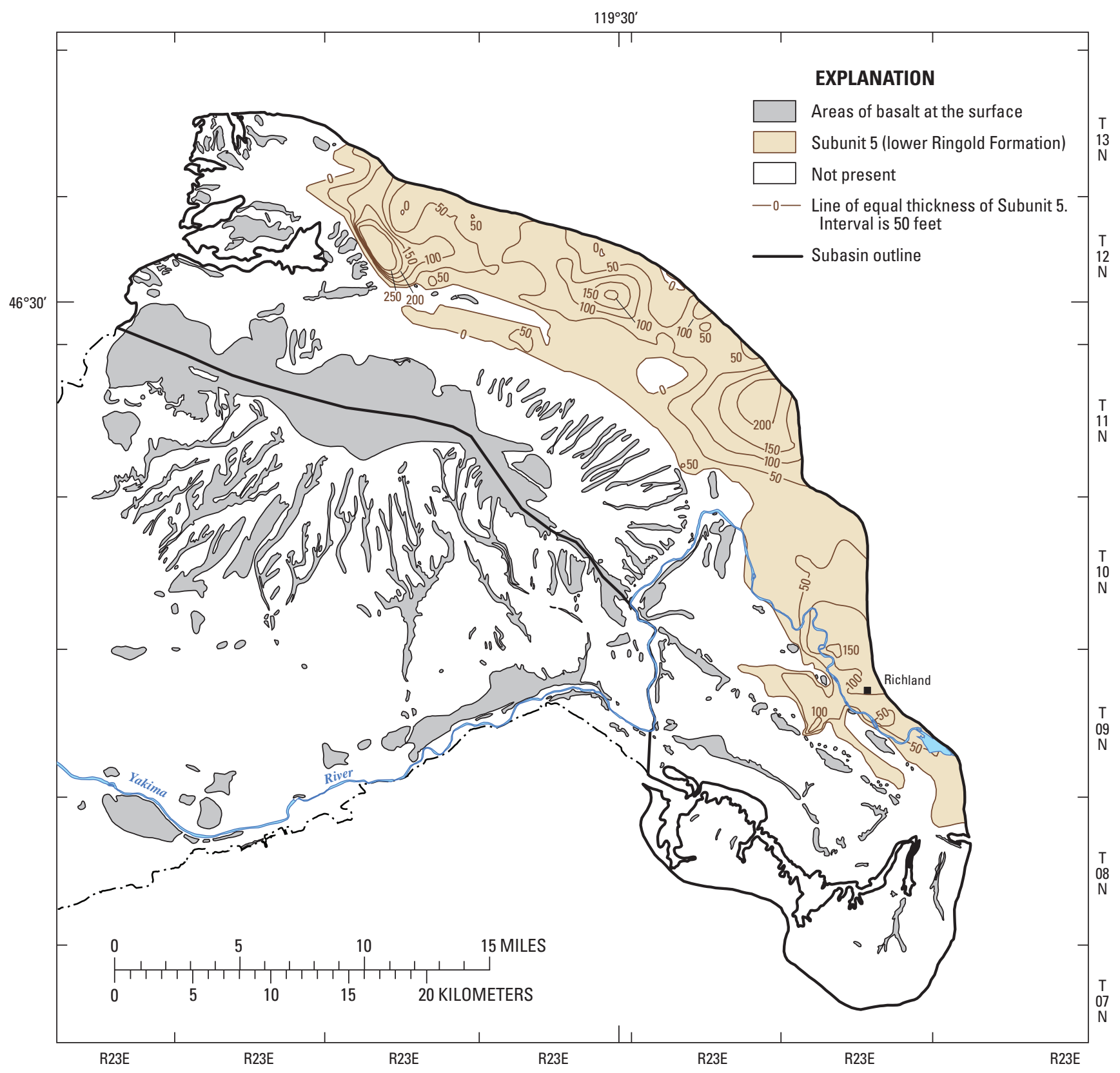

E. Subunit 5 - Fine-grained deposits of the lower Ringold Formation

Figure 8.-Continued. 


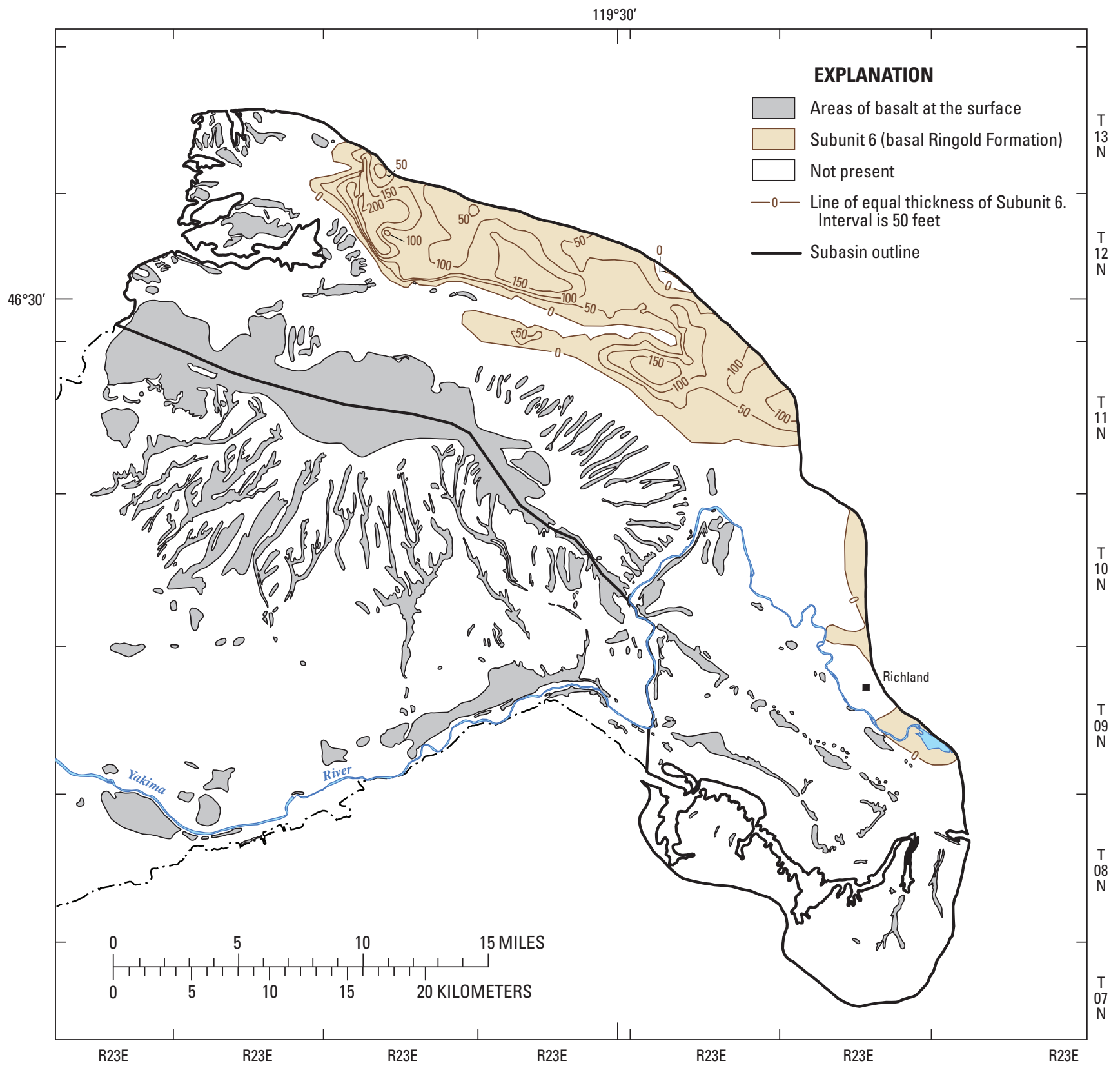

F. Subunit 6 - Coarse-grained basal Ringold Formation

Figure 8.-Continued. 


\section{Summary and Conclusions}

The Yakima River Basin aquifer system located in southcentral Washington encompasses about 6,200 square miles. The six structural sedimentary basins delineated, from north to south are: Roslyn, Kittitas, Selah, Yakima, Toppenish, and Benton. Information was collected, interpreted, and combined from simplified surficial geology maps, hydrogeologic contour maps from previous studies, and from about 4,700 well logs. This information was used to delineate the thicknesses of the hydrogeologic units in the basin-fill deposits in each of the six basins.

All data types were entered into a Geographical Information System software program in order to construct a gridded, 3D digital hydrogeologic framework for each basin using a 10-m cell size. Data types for each basin included a digital elevation model, simplified surficial geology, previously constructed hydrogeologic unit contour maps (where available), mapped extents of hydrogeologic units, well-log point values of the tops and thicknesses of a hydrogeologic unit, and interpretations from sections that were constructed for each basin. The original data interpretations were honored as much as possible in developing the 3D framework. The calculated top and thickness cell values and/or mapped contours for the hydrogeologic units were compared to the original well and/or mapped contour data and adjusted to most accurately reflect the original interpretations.

The hydrogeologic framework defines the physical, lithologic, and hydrogeologic characteristics of the hydrogeologic units that comprise the ground-water system in the individual basins. The hydrogeologic units vary by basin and the thickness, extent, and total basin thicknesses were described.

The Roslyn Basin basin-fill deposits, which total about $700 \mathrm{ft}$ thick, were divided and mapped into three hydrogeologic units and a total basin thickness. The hydrogeologic units consist of an upper coarse-grained unit, a clay unit, and a productive gravel unit.

The basin-fill deposits in the Kittitas, Selah, and Yakima Basins, which total about 2,000, 1,900, and $1,800 \mathrm{ft}$ thick, respectively, were divided and mapped into three hydrogeologic units and total basin thickness. The hydrogeologic units consist of alluvial, unconsolidated, and consolidated deposits.

The Toppenish Basin basin-fill deposits, which total about 1,200 ft thick, were divided and mapped into five hydrogeologic units based on previous work compiled by Campbell (unpub. maps produced for Yakama Nation, 2001). The five hydrogeologic units consist of fine-grained and coarse-grained unconsolidated deposits, consolidated deposits of the upper Ellensburg Formation, a blue clay deposit of the top of the Rattlesnake Ridge unit, and a coarse-grained deposit of the basal Rattlesnake Ridge unit.
The Benton Basin basin-fill deposits, which total about $870 \mathrm{ft}$ thick, were divided and mapped into two hydrogeologic units and a total basin thickness. The hydrogeologic units consist of unconsolidated and consolidated deposits. The unconsolidated deposits in the northeastern area of the basin were further divided into six subunits based on information compiled from previous investigations.

\section{Acknowledgments}

The cooperation of many well owners, tenants, and well drillers who supplied information and allowed access to wells is gratefully acknowledged. The field assistance and information supplied by the Yakama Nation, the U.S. Bureau of Reclamation, Washington State Department of Ecology, and the U.S. Geological Survey offices in Idaho, Oregon, and Washington also are acknowledged. Appreciation is expressed to Steve Reidel, Staff Geologist, Pacific Northwest National Laboratory; Eric Cheney, Associate Professor, Department of Earth and Space Sciences, University of Washington; and Newell Campbell, retired Geology Professor, Central Washington University for their assistance.

\section{Selected References}

Bureau of Reclamation, 1999, Yakima River Basin Water Enhancement Project, Washington, Final Programmatic Environmental Impact Statement: U.S. Department of Interior, Bureau of Reclamation, Pacific Northwest Region, Upper Columbia Area Office, Yakima, Washington, 197 p.

Cuffney, T.F., Meador, M.R., Porter, S.D., and Gurtz, M.E., 1997, Distribution of fish, benthic invertebrate, and algal communities in relation to physical and chemical conditions, Yakima River Basin, Washington, 1990: U.S. Geological Survey Water-Resources Investigations Report 96-4280, 94 p.

Drost, B.W., Cox, S.E., and Schurr, K.M., 1997, Changes in ground-water levels and ground-water budgets, from predevelopment to 1986, in parts of the Pasco Basin, Washington: U.S. Geological Survey Water-Resources Investigations Report 96-4086, 172 p.

Drost, B.W., and Whiteman, K.J., 1986, Surficial geology, structure, and thickness of selected geohydrologic units in the Columbia Plateau, Washington: U.S. Geological Survey Water-Resources Investigations Report 84-4326, 11 sheets.

Drost, B.W., Whiteman, K.J., and Gonthier, J.B., 1990, Geologic framework of the Columbia Plateau Aquifer System, Washington, Oregon, and Idaho: U.S. Geological Survey Water-Resources Investigations Report 87-4238, 10 p., 10 sheets.

Flaherty, N.M., 1975, The Yakima Basin and its water: Washington State University, Water Research Center, Pullman, Wa, 29 p. 
Frizzell, V.A., Jr., Tabor, R.W., Booth, D.B., Ort, K.M., and Waitt, R.B., Jr., 1984, Preliminary geologic map of the Snoqualmie Pass 1:100,000 quadrangle, Washington: U.S. Geological Survey Open-File Report 84-693, 36 p., 1 sheet, scale 1:100,000.

Fuhrer, G.J., McKenzie, S.W., Rinella, J.F., Sanzolone, R.F., and Skach, K.A., 1994, Surface-water-quality assessment of the Yakima River Basin in Washington: Analysis of major and minor elements in fine-grained streambed sediment 1987 with sections on Geology by Marshall Gannett: U.S. Geological Survey Open-File Report 93-30, 226 p., 3 sheets, scale 1:250,000.

Fuhrer, G.J., Morace, J.L., Johnson, H.M., Rinella, J.F., Ebbert, J.C., Embrey, S.S., Waite, I.R., Carpenter, K.D., Wise, D.R., and Hughes, C.A., 2004, Water quality in the Yakima River Basin, Washington, 1999-2000: U.S. Geological Survey Circular 1237, 44 p.

Glantz, M.H., 1982, Consequences and responsibilities in drought forecasting: The case of Yakima, 1977: Water Resr. Res., v. 18, no. 1, p. 3-13.

Gulick, G.W., and Korosec, M.A., 1990, Geologic map of the Banks Lake 1:100,000 quadrangle, Washington: Washington Division of Geology and Earth Resources, Open File-Report 90-6, 20 p., 1 sheet, scale 1:100,000.

Korosec, M.A., 1987, Geologic map of the Mount Adams quadrangle, Washington: Washington State Department of Natural Resources, Open-File Report 87-5, 41 p., 1 sheet, scale 1:100,000.

Kratz, M.R., 1978, Dilemmas, disruptions, but no disasterdrought in the Yakima basin, Washington, 1977: State Climatologist for Arizona Climatological Publications, Scientific Paper No. 3, 16 p.

Lane, R.C., 1988, Selected ground-water information for the Columbia Plateau regional aquifer system, Washington and Oregon, 1982-1985; Volume I: Geohydrology: U.S. Geological Survey Open-File Report 88-182, 236 p.

Meyers, C.W., and Price, S.M., 1979, Geologic studies of the Columbia Plateau, a status report: Rockwell International, Rockwell Hanford Operations RHO-BWI-ST-4, 520 p.

Meyers, C.W., and Price, S.M., 1981, Subsurface geology of the Cold Creek syncline, a status report: Rockwell International, Rockwell Hanford Operations RHO-BWI-ST$14,396 \mathrm{p}$.

Omernik, J.M., 1987, Ecoregions of the conterminous United States: Annals of the Association of American Geographers, v. 77, no. 1, p. 118-125.

Owens, R.R., 1995, The hydrogeology of the Kittitas Valley, Washington: Central Washington University, Master of Science Thesis, 205 p.

Parker, G.L., and Storey, F.B., 1913, Water powers of the Cascade Range, Part III, Yakima River Basin: U.S. Geological Survey Water-Supply Paper 369, 169 p., 18 pls.
Phillips, W.M., and Walsh, T.J., Geologic map of the northwest part of the Goldendale quadrangle, Washington: Washington Division of Geology and Earth Resources, Open-File Report 87-13, 9 p., 1 sheet, scale 1:100,000.

Reidel, S.P., and Fecht, K.R., 1994, Geologic map of the Richland 1:100,000 quadrangle, Washington: Washington Division of Geology and Earth Resources, Open-File Report 94-8, 21 p., scale 1:100,000.

Reidel, S.P., and Fecht, K.R., 1994, Geologic map of the Priest Rapids 1:100,000 quadrangle, Washington: Washington Division of Geology and Earth Resources, Open-File Report 94-13, 22 p., scale 1:100,000.

Russell, I.C., 1897, A reconnaissance of southeastern Washington: U.S. Geological Survey Water-Supply Paper 4, $96 \mathrm{p}$.

Schasse, H.W., 1987, Geologic map of the Mount Rainier quadrangle, Washington: Washington State Department of Natural Resources, Open-File Report 87-16, 43 p., 1 sheet, scale 1:100,000.

Schuster, E.J., 1994, Geologic maps of the east half of the Washington portion of the Goldendale 1:100,000 quadrangle and the Washington portion of the Hermiston 1:100,000 quadrangle: Washington State Department of Natural Resources, Open-File Report 94-9, 17 p., 1 sheet, scale 1:100,000.

Schuster, E.J., 1994, Geologic map of the east half of the Toppenish 1:100,000 quadrangle, Washington: Washington State Department of Natural Resources, Open-File Report 94-10, 15 p., 1 sheet, scale 1:100,000.

Schuster, E.J., 1994, Geologic map of the east half of the Yakima 1:100,000 quadrangle, Washington: Washington State Department of Natural Resources, Open-File Report 94-12, 19 p., 1 sheet, scale 1:100,000.

Sinclair, Kelsey, 1998, Stratigraphic correlation of the N2 Grande Ronde Basalt across Kittitas valley, Washington State: Central Washington University, Master of Science Thesis, $21 \mathrm{p}$.

Smith, G.O., 1901, Geology and water resources of a portion of Yakima County, Washington: U.S. Geological Survey Water-Supply and Irrigation Papers 55, 68 p.

Swanson, D.A., Anderson, J.L., Bentley, R.D., Byerly, G.R., Camp, V.E., Gardner, J.N., and Wright, T.L., 1979, Reconnaissance geologic map of the Columbia River Basalt group in eastern Washington and northern Idaho: U.S. Geological Survey Open-File Report 79-1363, 26 p., 12 sheets, scale 1:250,000.

Swanson, D.A., Brown, J.C., Anderson, J.L., Bentley, R.D., Byerly, G.R., Gardner, J.N., and Wright, T.L., 1979, Preliminary structure contour maps on the top of the Grand Ronde and Wanapum Basalts, eastern Washington and northern Idaho: U.S. Geological Survey Open-File Report 79-1364, 3 sheets. 
Systems Operations Advisory Committee, 1999, Report on biologically based flows for the Yakima River basin: Report to The Secretary of the Interior, May 1999, Yakima, Washington, Executive Summary, 6 chapters, Appendix A.

Tabor, R.W., Frizzell, V.A., Jr., Booth, D.B., Waitt, R.B., Whetten, J.T., and Zartman, F.E., 1993, Geologic map of the Skykomish River 30-by 60-minute quadrangle, Washington: U.S. Geological Survey Miscellaneous Investigations Series Map I-1963, 42 p., 1 sheet, scale 1:100,000.

Tabor, R.W., Frizzell, V.A., Jr., Whetten, J.T., Waitt, R.B., Swanson, D.A., Byerly, G.R., Booth, D.B., Hetherington, M.J., and Zartman, R.E., 1987, Geologic map of the Chelan 30-minute by 60-minute quadrangle, Washington: U.S. Geological Survey Miscellaneous Investigations Series Map I-1661, 33 p., 1 sheet, scale 1:100,000.

Tabor, R.W., Waitt, R.B., Jr., Frizzell, V.A., Jr., Swanson, D.A., Byerly, G.R., and Bentley, R.D., 1982, Geologic Map of the Wenatchee 1:100,000 quadrangle, central Washington: U.S. Geological Survey Miscellaneous Investigations Series Map I-1311, 26 p., 1 sheet, scale 1:100,000.

U.S. Department of Energy, 1988, Site characterization plan, reference repository location, Hanford Site, Washington; volume 1: U.S. Department of Energy, DOE/RW-0164, unpaginated.

U.S. District Court, 1945, Consent decree in the District Court of the United States for the Eastern District of Washington, Southern Division: Civil action No. 21, Spokane, Washington.
Vaccaro, J.J., 1995, Changes in the hydrometeorological regime in the Pacific Northwest: Proceedings of the 12th Annual Pacific Climate (PACLIM) Workshop, Asilomar, $\mathrm{Ca}$, Technical Report 46 of the Interagency Ecological Program for the Sacramento-San Joaquin Estuary, California Department of Water Resources, p. 143.

Walsh, T.J., 1986, Geologic map of the west half of the Toppenish quadrangle, Washington: Washington Division of Geology and Earth Resources, Open-File Report 86-3, 8 p., scale 1:100,000.

Walsh, T.J., 1986, Geologic map of the west half of the Yakima quadrangle, Washington: Washington Division of Geology and Earth Resources, Open-File Report 86-4, 12 p., scale 1:100,000.

Washington State Department of Ecology, 1998, Washington State Water Law, A Primer: WR-98-152, on-line on the World Wide Web, accessed October 2000, at URL http:// www.ecy.wa.gov/pubs/98152.

Whiteman, K.J., Vaccaro, J.J., Gonthier, J.B., and Bauer, H.H., 1994, The hydrogeologic framework and geochemistry of the Columbia Plateau aquifer system, Washington, Oregon, and Idaho: U.S. Geological Survey Professional Paper 1413-B, $73 \mathrm{p}$. 
Manuscript approved for publication, May 20, 2006

Prepared by the Publishing Network,

Publishing Service Center, Tacoma, Washington

Bill Gibbs

Robert Crist

Linda Rogers

Sharon Wahlstrom

For more information concerning the research in this report, contact the Director, Washington Water Science Center

U.S. Geological Survey, 1201 Pacific Avenue - Suite 600

Tacoma, Washington 98402

http://wa.water.usgs.gov 
